\title{
Emission inventory of anthropogenic air pollutants and VOC species in the Yangtze River Delta region, China
}

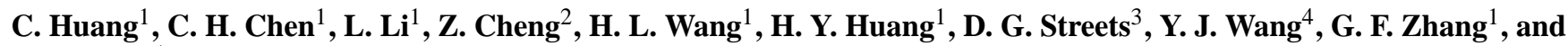 \\ Y. R. Chen ${ }^{1}$ \\ ${ }^{1}$ Shanghai Academy of Environmental Sciences, Shanghai 200233, China \\ ${ }^{2}$ Department of Environmental Science and Engineering, Tsinghua University, Beijing 100084, China \\ ${ }^{3}$ Argonne National Laboratory, Argonne, Illinois 60439, USA \\ ${ }^{4}$ School of Environmental and Chemical Engineering, Shanghai University, Shanghai 200444, China
}

Received: 20 November 2010 - Published in Atmos. Chem. Phys. Discuss.: 14 January 2011

Revised: 21 April 2011 - Accepted: 21 April 2011 - Published: 4 May 2011

\begin{abstract}
The purpose of this study is to develop an emission inventory for major anthropogenic air pollutants and VOC species in the Yangtze River Delta (YRD) region for the year 2007. A "bottom-up" methodology was adopted to compile the inventory based on major emission sources in the sixteen cities of this region. Results show that the emissions of $\mathrm{SO}_{2}, \mathrm{NO}_{\mathrm{x}}, \mathrm{CO}, \mathrm{PM}_{10}, \mathrm{PM}_{2.5}, \mathrm{VOCs}$, and $\mathrm{NH}_{3}$ in the YRD region for the year 2007 are $2392 \mathrm{kt}, 2293 \mathrm{kt}, 6697 \mathrm{kt}$, $3116 \mathrm{kt}, 1511 \mathrm{kt}, 2767 \mathrm{kt}$, and $459 \mathrm{kt}$, respectively. Ethylene, mp-xylene, o-xylene, toluene, 1,2,4-trimethylbenzene, 2,4-dimethylpentane, ethyl benzene, propylene, 1-pentene, and isoprene are the key species contributing $77 \%$ to the total ozone formation potential (OFP). The spatial distribution of the emissions shows the emissions and OFPs are mainly concentrated in the urban and industrial areas along the Yangtze River and around Hangzhou Bay. The industrial sources, including power plants other fuel combustion facilities, and non-combustion processes contribute about $97 \%$, $86 \%, 89 \%, 91 \%$, and $69 \%$ of the total $\mathrm{SO}_{2}, \mathrm{NO}_{\mathrm{x}}, \mathrm{PM}_{10}$, $\mathrm{PM}_{2.5}$, and VOC emissions. Vehicles take up $12.3 \%$ and $12.4 \%$ of the $\mathrm{NO}_{\mathrm{x}}$ and VOC emissions, respectively. Regarding OFPs, the chemical industry, domestic use of paint $\&$ printing, and gasoline vehicles contribute $38 \%, 24 \%$, and $12 \%$ to the ozone formation in the YRD region.
\end{abstract}

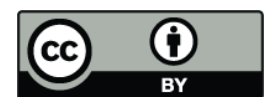

Correspondence to: $\mathrm{C}$. Huang

(huangc@saes.sh.cn)

\section{Introduction}

The complex and regional air pollution issues such as acid deposition, photochemical smog and haze caused by fine particles have become the most crucial topics for atmospheric environment research in the Yangtze River Delta (YRD) region in China. High ozone concentration and fine particle pollution were monitored to demonstrate the deteriorating regional air pollution situation in this region (Gao et al., 2009; Geng et al., 2009; Tie et al., 2009). Rapid growth of transportation, industries, and urbanization in the YRD region has become the major environmental driving force for the deterioration of urban and regional air quality. Therefore, the quantification of anthropogenic air pollutant emissions will be fundamental to the understanding of air pollutant emission levels, forecasting air quality status, and guiding air pollutant control strategies.

As the key to air pollutant emission control and management, emission inventories are being paid increasing attention by policy-makers and researchers. In the last decade, some emission inventories have been developed on multiscales in China, and most of them were compiled on national scale, even covering the whole of East Asia (Streets et al., 2003; Zhang, 2005; Ohara et al., 2007; Q. Zhang et al., 2009). The objectives of prior studies were mainly focused on the primary air pollutants from fuel combustion sources, like $\mathrm{SO}_{2}, \mathrm{NO}_{\mathrm{x}}$, and CO, etc. (Akimoto and Narita, 1994; Hao et al., 2002; Wang et al., 2005). After that, more studies began to involve other specific anthropogenic sources. Hao and Xie (2007) estimated a vehicular emission inventory for the whole of China. Lei et al. (2008) and Wei et al. (2008)

Published by Copernicus Publications on behalf of the European Geosciences Union. 
introduced PM and VOCs emission inventories based on surveys of the cement industry and other non-combustion industrial sources. Biomass burning emissions were also quantified as an important air pollution source in some studies (Cao et al., 2005; Yan et al., 2006). Besides primary air pollutants, researchers are gradually emphasizing the key precursors of secondary air pollution, in order to mitigate the complex air pollution of ozone and haze in the regions of China. The species in the VOCs and PM emissions were quantified for various emission sources in past studies (Streets et al., 2001; Cao et al., 2006; Bo et al., 2008), but confidence in the results was not high.

Emission factors are important parameters in the compilation of an emission inventory. Compared with European and American studies (EEA, 2006; USEPA, 2002), the fundamental work of emission factors in China is relatively weak. Former studies typically used an average emission factor for one fuel category in a whole sector, such as industry, domestic, and transport (Kato and Akimoto, 1992; Hao et al., 2002; Streets et al., 2003). To refine the emission inventory, Tian (2003), Wang et al. (2005), and Zhang (2005) improved the emission factors to facility level based on domestic measurement studies. Some recent studies reported more detailed emission inventories which can be refined to technology level for one facility category (Zhang et al., 2007; Lei et al., 2008).

Most of the emission inventories in China were established based on a top-down approach with low resolution of emission allocation, since the detailed activity data are hard to obtain. The previous studies on macro- or mesoscale emission inventories mainly depended on the statistical data of each administrative region. It is hard to allocate the emissions to the specific sources just based on the statistical data. Low-resolution inventories were thought to cause under-estimation of air pollution simulation in recent modeling studies (Liu et al., 2010). In order to support regional air pollution study and management in the city clusters of China, some studies introduced highly resolved regional air pollutant emission inventories by using a bottom-up approach (Zheng et al., 2009a, b; Li et al., 2011). Most of the studies on air pollutant emission inventories in the YRD region were still on the city-scale. Chen et al. (2006) and Zhang et al. (2008) have published the emission inventories for Shanghai and Hangzhou city, respectively. However, with city-scale emission inventories, it is hard to draw a whole picture of the total emission level and emission distribution for the YRD region.

Therefore, this paper aims to create an anthropogenic air pollutant emission inventory of the YRD region based on the year 2007. The pollutant types include $\mathrm{SO}_{2}, \mathrm{NO}_{\mathrm{x}}, \mathrm{CO}$, $\mathrm{PM}_{10}, \mathrm{PM}_{2.5}$, VOCs and $\mathrm{NH}_{3}$. VOCs species emissions were further developed to evaluate the ozone formation potential in the YRD region. After calculation, the emissions were distributed into $4 \mathrm{~km} \times 4 \mathrm{~km}$ resolved grids to describe the spatial characteristics of air pollutant emissions in the YRD region.

\section{Materials and methods}

\subsection{Domain of the study}

The YRD region is located on China's eastern coast and covers eight county-scale administrative regions in Jiangsu Province, which include Nanjing, Yangzhou, Tai'zhou, Nantong, Zhenjiang, Changzhou, Wuxi, and Suzhou; seven county-scale administrative regions of Zhejiang Province, namely Hangzhou, Huzhou, Jiaxing, Shaoxing, Ningbo, Zhoushan, and Taizhou; and lastly Shanghai municipality itself. Each administrative region is about $7000 \mathrm{~km}^{2}$ on average. Most of the regions consist of an urban area and several suburban areas, dozens of towns and villages, and extensive rural areas. Figure 1 shows the domain for the YRD regional emission inventory. The area is from $118.25^{\circ} \mathrm{E}$ to $122.42^{\circ} \mathrm{E}$, and $28.90^{\circ} \mathrm{N}$ to $33.30^{\circ} \mathrm{N}$, and is divided into 11979 grid cells with $4 \mathrm{~km} \times 4 \mathrm{~km}$ resolution.

The total area of the YRD region is about $110000 \mathrm{~km}^{2}$, representing $2 \%$ of China's total land area. However, the GDP (Gross Domestic Product) of the YRD region reached 6.55 trillion yuan, about $20 \%$ of total national GDP in 2007 (National Bureau of Statistics of China, 2008b). Correspondingly, the energy consumption in the YRD region reached 440 million tce, about $17 \%$ of the national total by the end of 2007. Coal was still the major energy category of the region, which contributed over $60 \%$ of the total energy consumed (National Bureau of Statistics of China, 2008a). The automobile population grew to 8 million units in 2007, which accounts for $18 \%$ of the national whole. The huge energy consumption and vehicle population induced a great amount of primary emissions and precursors in the region. Satellite observations of the tropospheric $\mathrm{NO}_{2}$ showed a sharp increase of $100 \%$ over the YRD region from the year 2000 to 2008, based on the measurements of the Global Ozone Monitoring Experiment (GOME) on the ESA European research satellite ERS-2 (http://www.temis.nl/airpollution/no2.html). Figure 1 shows the satellite observed $\mathrm{NO}_{2}$ concentration over eastern China in 2007.

\subsection{Methodology}

The study is focused on the major anthropogenic emission sources in the YRD region, so the main sources of the industry, transportation, residential and agriculture sectors are included in the inventory. The industry sectors include fuel combustion processes of power plants, boilers, furnaces, kilns, and non-combustion processes such as iron and steel manufacturing, oil refining, cement producing, etc. Transport emission sources mainly consist of vehicle exhaust and road dust emissions. The residential emission sources cover most of the emissions associated with daily life, such as residential fuel combustion emissions, domestic paint and solvent use, gas evaporation in service stations and so on. The agriculture emission sources mainly include the emissions 


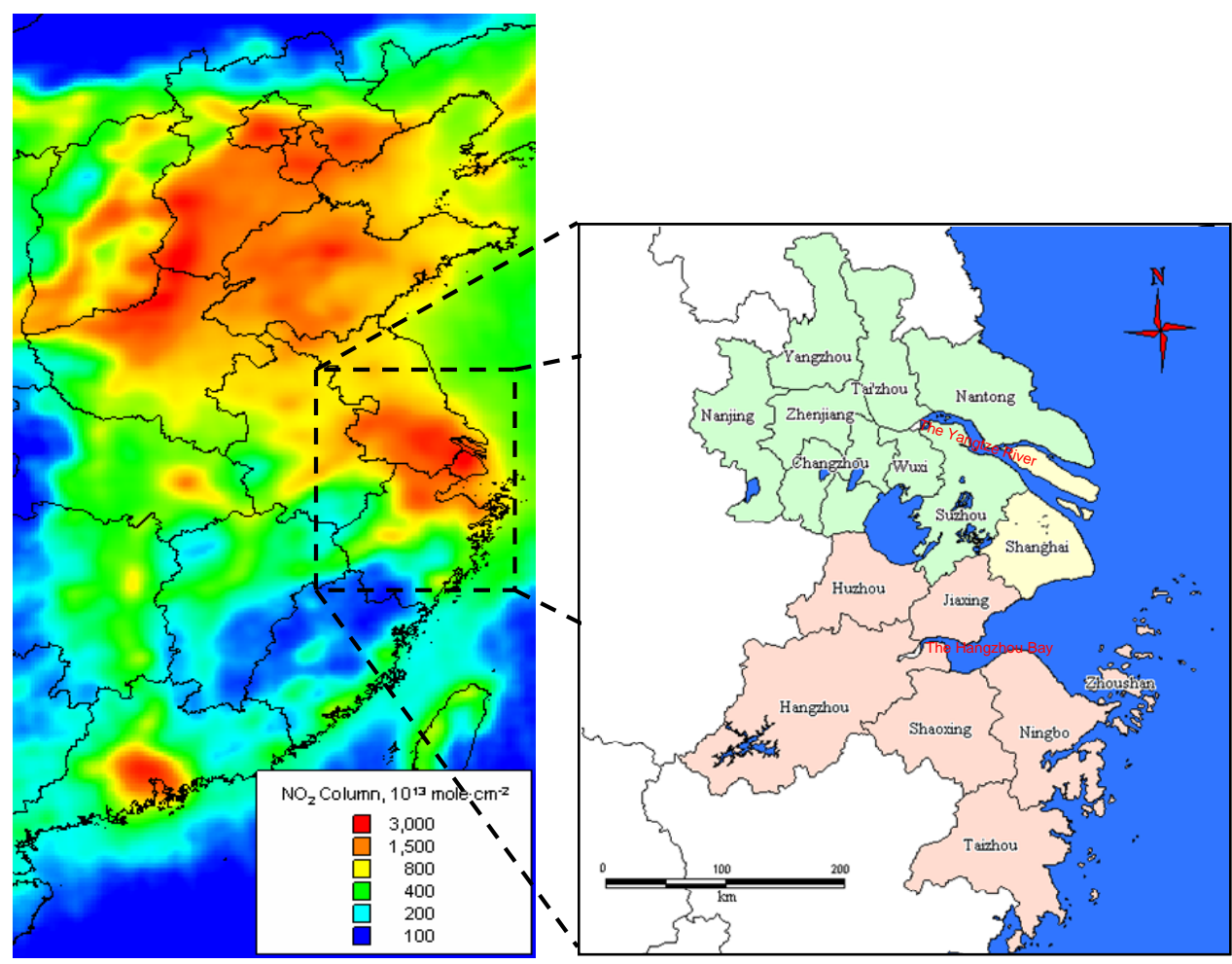

Fig. 1. Satellite observed tropospheric $\mathrm{NO}_{2}$ concentration in 2007 (left) and research domain of the YRD region (right).

from livestock feeding, fertilizer application and biomass burning. The pollutants included in this study are $\mathrm{SO}_{2}, \mathrm{NO}_{\mathrm{x}}$, $\mathrm{CO}, \mathrm{PM}_{10}, \mathrm{PM}_{2.5}$, VOCs and $\mathrm{NH}_{3}$. As an important precursor of photochemical smog, VOCs emissions were decomposed into various species by each kind of emission source.

A large amount of activity data on sources and emission factors of these pollutants was collected to compile the emission inventory of the YRD region in 2007. Then GIS technology was utilized to allocate the emissions based on the geographical information of the individual emission source types. Finally, the emissions in the YRD region were allocated to the $4 \mathrm{~km} \times 4 \mathrm{~km}$ grid cells.

\subsection{Determination of emission factors}

\subsubsection{Fuel-related combustion sources}

Fuel-related combustion sources in the YRD region mainly include power plants, boilers, furnaces, kilns, and some residential stoves. A nationwide campaign of pollution source census was conducted to get the basic data of these facilities one by one in each administrative region for the year of 2007. For regions where census data were not available, the activity data were collected from the national key pollution source lists reported by the government every year. These two datasets covered most of the industrial sources in the YRD region and supplied detailed information for in- dividual emission source calculation, such as geographical data, fuel type, fuel consumption, sulfur content, ash content, boiler type, capacity, and exhaust control efficiency, etc. Since there were no census data available for the emission sources in the commercial and civil sector, we collected fuel consumption data for a whole administrative region from its statistical yearbook and calculated the emissions with average emission factors. Relatively high uncertainty can be expected by use of statistical yearbook data compared with the census data.

The air pollutant emissions of fuel-related combustion are estimated using emission factor methods by Eq. (1):

$$
E_{i, j}=\sum_{j, k} A_{j, k} \mathrm{EF}_{i, j, k}\left(1-\eta_{i, j}\right)
$$

where, $A$ is the activity level of the source (e.g., annual fuel consumption); EF is the average emission factor; $\eta$ is the exhaust control efficiency; and $i, j, k$ represent the pollutant type, source category, and technology type, respectively.

For $\mathrm{SO}_{2}$ emissions, the annual inventory was compiled using the mass balance method by Eq. (2).

$\mathrm{EF}_{\mathrm{SO}_{2}}=2 \times C_{\mathrm{s}} \times P \times 1000$

where, $C_{\mathrm{s}}$ is the percentage of fuel sulfur content; $P$ is the conversion efficiency from sulfur to $\mathrm{SO}_{2}$. 
Table 1. Emission factors of coal combustion sources.

\begin{tabular}{|c|c|c|c|c|c|c|}
\hline \multirow[b]{2}{*}{ Source } & \multirow[b]{2}{*}{ Technology } & \multicolumn{5}{|c|}{ Emission factor $\left(\mathrm{kg} \mathrm{t}^{-1}\right)$} \\
\hline & & $\begin{array}{r}\mathrm{NO}_{\mathrm{x}} \\
\text { Zhang et al. (2007) }\end{array}$ & $\begin{array}{r}\text { CO } \\
\text { Wang et al. (2005) }\end{array}$ & $\begin{array}{r}\mathrm{PM}_{10} \\
\text { Zhang (2005) }\end{array}$ & $\begin{array}{r}\mathrm{PM}_{2.5} \\
\text { Zhang (2005) }\end{array}$ & $\begin{array}{r}\text { VOCs } \\
\text { Bo et al. (2008) }\end{array}$ \\
\hline Power plant & $\begin{array}{l}<100 \mathrm{MW} \text {, without LNB } \\
100 \sim 300 \mathrm{MW} \text {, without LNB } \\
\text { 100 300 MW, with LNB } \\
>300 \mathrm{MW} \text {, with LNB } \\
\text { stoker furnace } \\
\text { pulverized coal boiler } \\
\text { other }\end{array}$ & $\begin{array}{r}10.50 \\
8.85 \\
5.85 \\
5.55\end{array}$ & $\begin{array}{l}8.00 \\
2.00\end{array}$ & $\begin{array}{l}13.88 \\
46.00\end{array}$ & $\begin{array}{r}5.25 \\
12.00\end{array}$ & 0.15 \\
\hline Boiler & $\begin{array}{l}\text { hand-feed stoker furnace } \\
\text { automatic stoker furnace } \\
\text { fluidized-bed furnace } \\
\text { other }\end{array}$ & $\begin{array}{l}3.80 \\
4.00 \\
7.50\end{array}$ & $\begin{array}{r}124.00 \\
15.00 \\
2.00\end{array}$ & $\begin{array}{r}5.40 \\
5.40 \\
28.08\end{array}$ & $\begin{array}{l}1.89 \\
1.89 \\
5.40\end{array}$ & 0.18 \\
\hline Kiln & $\begin{array}{l}\text { shaft kiln } \\
\text { New-dry process } \\
\text { other rotary kiln } \\
\text { lime kiln } \\
\text { brick kiln } \\
\text { other }\end{array}$ & $\begin{array}{r}1.70 \\
15.30 \\
18.50 \\
1.70 \\
4.70\end{array}$ & $\begin{array}{r}155.70 \\
17.80 \\
17.80 \\
155.70 \\
150.00\end{array}$ & 5.40 & 1.89 & 0.18 \\
\hline $\begin{array}{l}\text { Commercial } \\
\text { Residential u }\end{array}$ & & $\begin{array}{l}3.75 \\
1.88\end{array}$ & $\begin{array}{l}75.00 \\
75.00\end{array}$ & $\begin{array}{l}3.50 \\
8.82\end{array}$ & $\begin{array}{l}2.00 \\
6.86\end{array}$ & $\begin{array}{l}0.60 \\
0.60\end{array}$ \\
\hline
\end{tabular}

The emission factors of $\mathrm{NO}_{\mathrm{x}}, \mathrm{CO}, \mathrm{PM}_{10}, \mathrm{PM}_{2.5}$, and VOCs were taken directly from the latest literature. Domestic measurements or relative studies in recent years have priority to be applied in this study. Foreign studies in line with the current technology level in China are used when there is no domestic information available.

The literature reviews of previous studies obtain a range of $2.38-10.0 \mathrm{~kg} \mathrm{t}^{-1}$ for $\mathrm{NO}_{\mathrm{x}}$ emission factors (Kato and Akimoto, 1992; Hao et al., 2002; Streets et al., 2003). To better understand the $\mathrm{NO}_{\mathrm{x}}$ emission level of coal-fired boilers in China, Tian (2003) studied more than 100 power plant boilers and obtained a mix of $\mathrm{NO}_{\mathrm{x}}$ emission factors of various boiler types with and without LNB. Based on Tian's study, Zhang et al. (2007) predicted the $\mathrm{NO}_{\mathrm{x}}$ emission factors of coal-fired boilers for 1995-2004 in China, which we believe are more representative of the current $\mathrm{NO}_{\mathrm{x}}$ emission level of the facilities in the YRD region.

Previous studies illustrate the big differences of $\mathrm{CO}$ emission factors between different types of combustion facilities. Ge et al. (2001) obtained the average CO emission factor $\left(15 \mathrm{~kg} \mathrm{t}^{-1}\right)$ of automatic stoker furnaces based on measurements. While the $\mathrm{CO}$ emission factor of hand-feed stoker furnaces could be 7 times higher according to USEPA's study (2002). Zhang et al. (2000) tested 19 household stoves and obtained a range of $19-170 \mathrm{~kg} \mathrm{t}^{-1}$ for $\mathrm{CO}$ emission factor. Based on these studies, Wang et al. (2005) summarized the $\mathrm{CO}$ emission factors of each kind of fuel combustion source in China, so we used the CO emission factors from the study of Wang et al. (2005).
PM emission factors usually depend on ash content in coal, boiler technology, and the efficiency of exhaust control. There have been few PM emission measurements made in China. Zhang (2005) summarized the domestic and foreign studies from USEPA (2002), Klimont et al. (2002a), and Zhang et al. (2002) and reported a group of $\mathrm{PM}_{10}$ and $\mathrm{PM}_{2.5}$ emission factors, which we have listed in Tables 1 and 2 according to the technology level of the facilities in China. The emission factors of other pollutants were mainly based on European or American results due to the lack of corresponding measurement data in China. VOCs emission factors came from the study of Bo et al. (2008). $\mathrm{NH}_{3}$ emission factors were negligible for fuel combustion sources.

The emission factors from coal combustion sources with different technologies are listed in Table 1. The emission factors of other fuel types are given in Table 2.

\subsubsection{Non-combustion sources in industry}

Production processes including cement processing, iron and steel manufacturing, oil refining, etc. are other important emission sources in the industrial sector. This study uses the emission factor method shown in Eq. (1) to calculate non-combustion emissions in industrial processes. Owing to the lack of local studies in China, the emission factors were mainly taken from the research findings of the United States or Europe. USEPA (2002) reports the emission factors of each industrial process source category in its AP-42 emission factor compilation. The emission factors of major 
Table 2. Emission factors of other fuel combustion sources in industry.

\begin{tabular}{llrrrrrl}
\hline Pollutant & Source & $\begin{array}{r}\text { Coal gas } \\
\left(\mathrm{g} \mathrm{m}^{-3}\right)\end{array}$ & $\begin{array}{r}\text { Natural gas } \\
\left(\mathrm{g} \mathrm{m}^{-3}\right)\end{array}$ & $\begin{array}{r}\text { LPG } \\
\left(\mathrm{kg} \mathrm{t}^{-1}\right)\end{array}$ & $\begin{array}{r}\text { Diesel } \\
\left(\mathrm{kg} \mathrm{t}^{-1}\right)\end{array}$ & $\begin{array}{r}\text { Fuel oil } \\
\left(\mathrm{kg} \mathrm{t}^{-1}\right)\end{array}$ & Reference \\
\hline $\mathrm{NO}_{\mathrm{x}}$ & power plant & & 4.10 & & 7.40 & 10.06 & Tian (2003) \\
& $\begin{array}{l}\text { Other industry } \\
\text { residential use }\end{array}$ & 0.74 & 2.09 & 2.63 & 9.62 & 5.84 & Tian (2003) \\
& & 1.46 & $1.58 / 0.88$ & 5.77 & 3.50 & Tian (2003) \\
$\mathrm{CO}$ & - & 1.30 & 1.30 & 0.36 & 0.60 & 0.60 & Wang et al. (2005) \\
$\mathrm{PM}_{10}$ & power plant & & 0.12 & & 0.50 & 0.85 & Zhang (2005) \\
& Other industry & 0.20 & 0.12 & 0.08 & 0.50 & 1.03 & Zhang (2005) \\
& residential use & 0.20 & 0.12 & 0.08 & 0.50 & 1.20 & Zhang (2005) \\
$\mathrm{PM}_{2.5}$ & power plant & & 0.12 & & 0.50 & 0.62 & Zhang (2005) \\
& Other source & 0.20 & 0.12 & 0.08 & 0.50 & 0.67 & Zhang (2005) \\
& residential use & 0.20 & 0.12 & 0.08 & 0.50 & 0.90 & Zhang (2005) \\
$\mathrm{VOCS}$ & power plant & & 0.18 & & 0.13 & 0.13 & Bo et al. (2008) \\
& Other source & 0.00044 & 0.18 & 0.19 & 0.15 & 0.15 & Bo et al. (2008) \\
& residential use & 0.00044 & 0.18 & 0.19 & 0.15 & 0.15 & Bo et al. (2008) \\
\hline
\end{tabular}

PM emission sources in this study, such as coke production, iron \& steel manufacturing, steel foundries, ferroalloy, and aluminum products, etc., are mainly taken from AP-42 with some adjustments to reflect poorer performance and lower particulate collection efficiencies of the technology level in China. VOCs emission from industrial processes is an important source which contributes about $32 \%$ of the total in China according to a previous study (Wei et al., 2008). For the industrial processes of beer \& spirits manufacturing, paint \& ink, plastic, fiber and tire production, we collect the emission factors from the studies of Klimont et al. (2002b) and Bo et al. (2008), which originate from European and American studies, respectively. The VOCs emission factor of oil refining is hard to determine because of its complicated processes and miscellaneous fugitive segments. USEPA (2002) reported an overall THC emission factor of $3.54 \mathrm{~kg} \mathrm{t}^{-1}$ for the refinery industry without control. European studies obtained lower emission factors, which are about $1.63 \mathrm{~kg} \mathrm{t}^{-1}$ (Passant et al., 1998) and $1.05 \mathrm{~kg} \mathrm{t}^{-1}$ (EEA, 2006). We cite a median value $\left(2.65 \mathrm{~kg} \mathrm{t}^{-1}\right)$ reported by Klimont et al. (2002b) to represent the current level of oil refining in the YRD region. VOCs emission factors of industrial uses of paint and solvent have large differences in the different literatures (USEPA, 2002; EEA, 2006; Wei et al., 2008; Bo et al., 2008). Based on the fact that the paint used in industry is mainly conventional solvent paint with high solvent content, we determine the emission rates of paint application, printing, degreasing operations, and solvent use by Klimont et al. (2002b) and USEPA (2002). The emission factors of cement and bricks manufacturing are based on domestic studies (Lei et al., 2008; C. Y. Zhang et al., 2009). Table 3 lists the emission factors and their references for non-combustion industrial process sources.

\subsubsection{Road transport emission sources}

The IVE model (ISSRC, 2004) is used to calculate vehicle emissions during the phases of driving, cold start and VOCs evaporation. According to the model needs, we classify the vehicle fleet into light-duty car, light-duty truck, taxi, urban bus, heavy-duty bus, heavy-duty truck, and motorcycle. The study surveys the numbers of each vehicle type from the statistical yearbook of each administrative region. To prepare the fleet files of each city, detailed information about vehicle technology, fuel type, emission standard, and vehicle age is surveyed in the representative cities of Nanjing, Hangzhou, and Shanghai. The average annual travel mileage of each vehicle type is simultaneously obtained based on the relationship between vehicle ages and odometers in these cities (H. K. Wang et al., 2008). After that, we assume fuel economy data (mileage per liter of fuel) for each vehicle and fuel type and obtain total gasoline and diesel consumption in each administrative region by multiplying the fuel economies by annual travel mileages. Some adjustments are made when there are large differences between the predicted data and statistical data. Other input data on driving cycle, fuel quality, and environmental conditions in the study were obtained from existing studies in the representative cities of Shanghai and Hangzhou (Guo et al., 2007; H. K. Wang et al., 2008). Some real-world test data of heavy-duty diesel vehicles were used to adjust the emission factors calculated by the model (Chen et al., 2007).

Road dust emission is another important source of pollution from the transport sector. The approach to estimating road dust emission is adopted from USEPA (2002), mainly related to such parameters as average weight of the vehicles traveling on the road, road surface silt loading, and a particle 
Table 3. Emission factors of industrial process sources.

\begin{tabular}{|c|c|c|c|c|c|c|c|c|c|c|}
\hline Process & Activity rate & Unit & $\mathrm{SO}_{2}$ & $\mathrm{NO}_{\mathrm{x}}$ & $\mathrm{CO}$ & $\mathrm{PM}_{10}$ & $\mathrm{PM}_{2.5}$ & VOCs & $\mathrm{NH}_{3}$ & Refence \\
\hline Vegetable oil processing & production & $\mathrm{kg} \mathrm{t}^{-1}$ & & & & & & 2.45 & & USEPA (2002) \\
\hline Beer manufacturing & production & $\mathrm{kg} \mathrm{m}^{-1}$ & & & & & & 0.20 & & Klimont et al. (2002) \\
\hline Spirits manufacturing & production & $\mathrm{kg} \mathrm{m}^{-1}$ & & & & & & 20.00 & & Klimont et al. (2002) \\
\hline Oil refining & crude oil feed & $\mathrm{kg} \mathrm{t}^{-1}$ & 1.58 & 0.22 & & & & 2.65 & & Klimont et al. (2002) \\
\hline Coke production & coal charged & $\mathrm{kg} \mathrm{t}^{-1}$ & 2.01 & 0.02 & 0.64 & 2.75 & 1.75 & 2.10 & 0.09 & USEPA (2002) \\
\hline Synthetic Ammonia & production & $\mathrm{kg} \mathrm{t}^{-1}$ & 0.03 & & 7.90 & & & 4.72 & 2.10 & USEPA (2002) \\
\hline Sulfuric Acid & production & $\mathrm{kg} \mathrm{t}^{-1}$ & 7.00 & & & & & & & USEPA (2002) \\
\hline Urea & production & $\mathrm{kg} \mathrm{t}^{-1}$ & & & & 1.74 & 1.50 & & 9.69 & USEPA (2002) \\
\hline Paint production & production & $\mathrm{kg} \mathrm{t}^{-1}$ & & & & & & 15.00 & & Klimont et al. (2002) \\
\hline Ink production & production & $\mathrm{kg} \mathrm{t}^{-1}$ & & & & & & 30.00 & & Klimont et al. (2002) \\
\hline Plastic processing & production & $\mathrm{kg} \mathrm{t}^{-1}$ & & & & & & 2.20 & & Bo et al. (2008) \\
\hline Synthetic fibre & production & $\mathrm{kg} \mathrm{t}^{-1}$ & & & & & & 73.40 & & Bo et al. (2008) \\
\hline Tyres production & production & $\mathrm{kg} \mathrm{tyre}^{-1}$ & & & & & & 0.29 & & Klimont et al. (2002) \\
\hline Synthetic rubber & production & $\mathrm{kg} \mathrm{t}^{-1}$ & & & & & & 15.00 & & Klimont et al. (2002) \\
\hline Cement manufacturing & production & $\mathrm{kg} \mathrm{t}^{-1}$ & & & & 8.05 & 3.40 & & & Lei et al. (2008) \\
\hline Bricks production & production & $\mathrm{kg} \mathrm{t}^{-1}$ & & & & 0.13 & 0.04 & & & C. Y. Zhang et al. (2009) \\
\hline Iron manufacturing & production & $\mathrm{kg} \mathrm{t}^{-1}$ & 0.30 & 0.09 & 40.50 & 0.72 & 0.45 & & & USEPA (2002) \\
\hline Steel manufacturing & Production & $\mathrm{kg} \mathrm{t}^{-1}$ & & & 9.00 & 11.78 & 8.62 & 0.06 & & USEPA (2002) \\
\hline Steel foundries & Production & $\mathrm{kg} \mathrm{t}^{-1}$ & & & & 3.58 & 1.70 & & & USEPA (2002) \\
\hline Ferroalloy & production & $\mathrm{kg} \mathrm{t}^{-1}$ & & & & 3.61 & 2.79 & & & USEPA (2002) \\
\hline Aluminum products & production & $\mathrm{kg} \mathrm{t}^{-1}$ & & & & 2.63 & 2.08 & & & USEPA (2002) \\
\hline Paint application & paint used & $\mathrm{kg} \mathrm{t}^{-1}$ & & & & & & 730.00 & & Klimont et al. (2002) \\
\hline Print & Ink used & $\mathrm{kg} \mathrm{t}^{-1}$ & & & & & & 300.00 & & Klimont et al. (2002) \\
\hline Degreasing operations & solvent used & $\mathrm{kg} \mathrm{t}^{-1}$ & & & & & & 900.00 & & Klimont et al. (2002) \\
\hline Solvent use & solvent used & $\mathrm{kg} \mathrm{t}^{-1}$ & & & & & & 300.00 & & USEPA (2002) \\
\hline
\end{tabular}

size multiplier. However, our estimation of this source is very simple and has high uncertainty, since there is little local information that can be compared. The parameters of road surface silt loading and particle size multiplier are determined by the studies of Sun et al. (2003) and Huang et al. (2006) with some modifications for different road types of different areas in the YRD region.

\subsubsection{Fugitive VOCs emission sources}

The fugitive VOCs emission sources considered in this study mainly consist of domestic paint use for building and furniture, domestic solvent use, and oil/gas evaporation. For the architectural and domestic use of paint, this study uses paint consumption as the activity unit for these activities and for vehicle treatment. The emission factors of domestic paint and solvent uses and waste landfills are taken from Klimont et al. (2002). The volatilization and leakage of VOCs emissions from the distribution and storage of petroleum products mainly involve liquid loading losses, tank breathing losses, and vehicle refueling operation losses. Bo et al. (2008) indicate that most gas stations adopted underground tanks and had no control in vehicle refueling operations by 2007 . Therefore, we select the emission factors from that study. The activity data of each source come from the statistical yearbook of each administrative region, and the emission factors and their references are listed in Table 4.

\subsubsection{Anthropogenic ammonia sources}

Anthropogenic ammonia sources include livestock feeding, $\mathrm{N}$-fertilizer application, sewage treatment, waste landfills, and human discharge in this study. The emission rates of major ammonia sources are influenced by local geography and climate conditions, so the emission factors mainly come from domestic studies (Dong et al., 2009; Zhang et al., 2010; Yin et al., 2010). Only the human discharge emission factor comes from a European study (EEA, 2006), since there is no local study available. The activity data of these sources are collected from the annual statistical data of each administrative region. The emission factors of each source type are listed in Table 5.

\subsubsection{Biomass burning}

Biomass burning emissions in this study come from household use and crop residue burning. The burning mass is estimated based on the statistical data of crop production, residue/crop ratio, and the percentage of burning. Most emission factors used in studies of biomass burning emissions originate from Andreae and Merlet (2001) and Zhang 
Table 4. Emission factors of fugitive VOCs emission sources.

\begin{tabular}{lllrl}
\hline Source & Activity rate & Unit & Emission factor & Reference \\
\hline Domestic paint use & paint used & $\mathrm{kg} \mathrm{t}^{-1}$ & 0.36 & Klimont et al. (2002) \\
Domestic solvent use & solvent used & $\mathrm{kg} \mathrm{capita}^{-1}$ & 0.20 & Klimont et al. (2002) \\
Vehicle treatment & cars registered & $\mathrm{kg} \mathrm{vehicle}^{-1}$ & 1.11 & Klimont et al. (2002) \\
Waste landfills & amount of waste & $\mathrm{kg} \mathrm{t}^{-1}$ & 0.23 & Klimont et al. (2002) \\
Oil storage & & & & \\
Crude oil & storage rate & $\mathrm{kg} \mathrm{t}^{-1}$ & 0.12 & Bo et al. (2008) \\
Gasoline & storage rate & $\mathrm{kg} \mathrm{t}^{-1}$ & 0.16 & Bo et al. (2008) \\
Underground tank filling & gasoline consumed & $\mathrm{kg} \mathrm{t}^{-1}$ & 1.16 & Bo et al. (2008) \\
Tank breathing and emptying & gasoline consumed & $\mathrm{kg} \mathrm{t}^{-1}$ & 0.16 & Bo et al. (2008) \\
Vehicle refueling operations & & & & \\
displacement losses (uncontrolled) & gasoline consumed & $\mathrm{kg} \mathrm{t}^{-1}$ & 1.74 & Bo et al. (2008) \\
Spillage & gasoline consumed & $\mathrm{kg} \mathrm{t}^{-1}$ & 0.11 & Bo et al. (2008) \\
\hline
\end{tabular}

Table 5. Emission factors of anthropogenic ammonia emission sources.

\begin{tabular}{lllrl}
\hline Source & Activity rate & Unit & Emission factor & Reference \\
\hline Livestock & & & & \\
Dairy cattle & livestock & $\mathrm{kg} \mathrm{N} \mathrm{head}^{-1}$ & 21.93 & Zhang et al. (2010) \\
Other cattle & livestock & $\mathrm{kg} \mathrm{N} \mathrm{head}^{-1}$ & 7.31 & Zhang et al. (2010) \\
Pig & livestock & $\mathrm{kg} \mathrm{N} \mathrm{head}^{-1}$ & 4.61 & Zhang et al. (2010) \\
Sheep and goat & livestock & $\mathrm{kg} \mathrm{N} \mathrm{head}^{-1}$ & 2.24 & Zhang et al. (2010) \\
Horse & livestock & $\mathrm{kg} \mathrm{N} \mathrm{head}^{-1}$ & 5.66 & Zhang et al. (2010) \\
Poultry & livestock & $\mathrm{kg} \mathrm{N} \mathrm{head}^{-1}$ & 0.41 & Zhang et al. (2010) \\
N-fertilizer application & fertilizer applied & $\mathrm{kg} \mathrm{kg}^{-1}$ & 16.81 & Dong et al. (2009) \\
Sewage treatment & amount of sewage & $\mathrm{kg} \mathrm{m}^{-3}$ & 0.0032 & Yin et al. (2010) \\
Waste landfills & amount of waste & $\mathrm{kg} \mathrm{t}^{-1}$ & 0.56 & Yin et al. (2010) \\
Human discharge & capita & $\mathrm{kg} \mathrm{capita}^{-1}$ & 0.05 & EEA (2006) \\
\hline
\end{tabular}

et al. (2000). We use the summarized emission factors reported by Cao et al. (2005) in this study.

\subsection{Speciation of VOC emissions}

VOC emissions were broken down into their chemical constituents based on the species profiles of the various emission sources. Sources included were coal burning, petrochemical industry, coking industry, paint and solvent use, gasolinefueled vehicles, diesel-fueled vehicles, gasoline evaporation, andbiomass burning. Some local experimental results from the coking industry were adopted to determine the source profiles; however, most of the source profile data were cited from the work of Liu et al. (2008), B. G. Wang et al. (2008) and Yuan et al. (2010).

In order to evaluate the impact of the VOC species on ozone formation, the ozone formation potentials (OFP) of each of the VOC species was calculated by multiplying the emissions by its corresponding maximum increment reactiv- ity (MIR) factor (Carter, 1994). The total OFP of each source can be calculated by summarizing all of the OFPs of individual VOC species, as shown in Eq. (3).

$\mathrm{OFP}_{i}=\sum_{j=1} E_{i j} \times \mathrm{MIR}_{j}$

where, $\mathrm{OFP}_{i}$ is the ozone formation potential of source $i$, $E_{i j}$ is the VOC emission of source $i, \mathrm{MIR}_{j}$ is the maximum increment reactivity for the $j_{\text {th }}$ chemical species.

\subsection{Methodology for emission allocation}

The method for the regional emission allocation in the study depends on the source type and its spatial characteristics. For the power plants, boilers, furnaces and other stationary fuel combustion facilities, the emissions were spatially allocated into the appropriate grid cells based on their longitude and latitude. Other small distributed industrial sources and noncombustion emissions were treated as area sources. Areasource emissions were first estimated at county scale and 
Table 6. Air pollutant emission inventory of the cities in the YRD region in 2007.

\begin{tabular}{|c|c|c|c|c|c|c|c|c|c|}
\hline \multirow[b]{2}{*}{ Province } & \multirow[b]{2}{*}{ City } & \multirow[b]{2}{*}{ Distance to Shanghai $/ \mathrm{km}$} & \multicolumn{7}{|c|}{ Annual air pollutant emissions/kt } \\
\hline & & & $\mathrm{SO}_{2}$ & $\mathrm{NO}_{\mathrm{x}}$ & $\mathrm{CO}$ & $\mathrm{PM}_{10}$ & $\mathrm{PM}_{2.5}$ & VOCs & $\mathrm{NH}_{3}$ \\
\hline \multirow[t]{8}{*}{ Jiangsu } & Suzhou & 85 & 281.7 & 368.6 & 1205.1 & 389.2 & 208.1 & 483.3 & 26.3 \\
\hline & Nantong & 98 & 139.4 & 90.5 & 308.9 & 111.6 & 56.8 & 87.7 & 71.1 \\
\hline & Wuxi & 117 & 261.4 & 183.7 & 488.0 & 347.5 & 167.8 & 191.7 & 26.8 \\
\hline & Changzhou & 158 & 145.4 & 90.7 & 455.4 & 211.6 & 98.8 & 73.2 & 16.3 \\
\hline & Tai'zhou & 200 & 18.2 & 52.5 & 148.7 & 64.9 & 31.2 & 62.8 & 32.9 \\
\hline & Zhenjiang & 220 & 131.6 & 103.3 & 128.5 & 208.3 & 96.4 & 45.9 & 14.3 \\
\hline & Yangzhou & 234 & 43.9 & 110.4 & 164.8 & 81.8 & 48.3 & 58.1 & 50.7 \\
\hline & Nanjing & 272 & 221.0 & 144.2 & 739.7 & 255.9 & 129.7 & 153.2 & 24.1 \\
\hline \multirow[t]{7}{*}{ Zhejiang } & Jiaxing & 85 & 120.9 & 114.3 & 203.3 & 219.7 & 97.4 & 58.0 & 36.7 \\
\hline & Huzhou & 137 & 81.3 & 71.5 & 144.2 & 190.0 & 83.2 & 53.7 & 20.1 \\
\hline & Ningbo & 150 & 254.8 & 211.0 & 284.0 & 211.6 & 111.6 & 150.3 & 25.4 \\
\hline & Zhoushan & 157 & 4.2 & 15.7 & 18.6 & 10.4 & 6.1 & 17.9 & 1.7 \\
\hline & Shaoxing & 163 & 135.0 & 105.0 & 213.5 & 196.8 & 88.2 & 287.3 & 21.3 \\
\hline & Hangzhou & 164 & 126.2 & 134.5 & 482.5 & 282.0 & 129.3 & 391.6 & 29.6 \\
\hline & Taizhou & 267 & 28.1 & 117.1 & 156.5 & 69.1 & 38.5 & 66.0 & 19.0 \\
\hline Shanghai & & 0 & 398.8 & 380.0 & 1555.5 & 265.5 & 119.2 & 586.9 & 42.6 \\
\hline Total & & - & 2391.8 & 2292.9 & 6697.1 & 3115.7 & 1510.8 & 2767.4 & 458.9 \\
\hline
\end{tabular}

then allocated to grid cells according to $1 \mathrm{~km} \times 1 \mathrm{~km}$ resolution level GDP distribution data in China (RESDC, 2003). The other anthropogenic emissions are deemed to be related to the distribution of population density. Therefore, these kinds of emissions were spatially allocated into grid cells based on $30^{\prime \prime} \times 30^{\prime \prime}$ resolution gridded population densities from 2006 LandScan Asia Population data (ORNL, 2007).

\section{Results and discussion}

\subsection{Air pollutant emissions and distributions}

The anthropogenic emission inventories in the sixteen administrative regions of the YRD region for the year 2007 are summarized in Table 6. The total emissions of $\mathrm{SO}_{2}, \mathrm{NO}_{\mathrm{x}}$, $\mathrm{CO}, \mathrm{PM}_{10}, \mathrm{PM}_{2.5}, \mathrm{VOCs}$, and $\mathrm{NH}_{3}$ were $2392 \mathrm{kt}, 2293 \mathrm{kt}$, $6697 \mathrm{kt}, 3116 \mathrm{kt}, 1511 \mathrm{kt}, 2767 \mathrm{kt}$, and $459 \mathrm{kt}$, respectively. Shanghai, Suzhou, Wuxi, Ningbo, Hangzhou, and Nanjing are the six largest contributors. These regions totally account for $65 \%, 62 \%, 71 \%, 56 \%, 57 \%, 71 \%$, and $38 \%$ of $\mathrm{SO}_{2}$, $\mathrm{NO}_{\mathrm{x}}, \mathrm{CO}, \mathrm{PM}_{10}, \mathrm{PM}_{2.5}, \mathrm{VOCs}$, and $\mathrm{NH}_{3}$ emission. It is worthwhile to mention that flue-gas desulfurization (FGD) projects are being implemented at power plants in the YRD region during the national 11th Five-Year Plan (2006-2010). By the end of 2007, about $40 \%$ of power plants had accomplished the installation of FGD units. The units achieved a $\mathrm{SO}_{2}$ emission reduction of approximately $153 \mathrm{kt}$, assuming their removal efficiencies reached $90 \%$. Another $79 \mathrm{kt} \mathrm{SO} 2$ emission could be expected before the end of 2010, provided that the remaining planned FGD installation is implemented.

Figure 2 illustrates the spatial allocation of emissions and relative concentrations of $\mathrm{SO}_{2}, \mathrm{NO}_{2}$, and $\mathrm{PM}_{10}$ (concentrations of Shanghai are equivalent to (1) in the YRD region. The annual average concentrations of $\mathrm{SO}_{2}, \mathrm{NO}_{2}$, and $\mathrm{PM}_{10}$ came from the annual statistical data of the monitoring network in each administrative region (JSEPB, 2008; ZJEPB, 2008; SEPB, 2008). Figure 2a-e show that the highest emission intensities of $\mathrm{SO}_{2}, \mathrm{NO}_{\mathrm{x}}, \mathrm{PM}_{10}, \mathrm{PM}_{2.5}$, and VOCs are located along the banks of the Yangtze River and Hangzhou Bay. The area along the southern bank of the Yangtze River has a lot of industrial zones for manufacturing, steel production, chemical production, etc. The major emission sources of Hangzhou Bay are oil refining and its downstream industry. High emission intensities in the city centers of Shanghai, Hangzhou, Nanjing, and Wuxi mainly come from on-road vehicles. As $\mathrm{NH}_{3}$ emission mainly comes from the agriculture sector, high $\mathrm{NH}_{3}$ emission intensity is distributed in rural areas of Nantong, Jiaxing, Yangzhou, Taizhou, and the suburban area of Shanghai, as shown in Fig. 2f. The emission distributions in the YRD region are reasonably correlated with $\mathrm{SO}_{2}, \mathrm{NO}_{2}$, and $\mathrm{PM}_{10}$ annual concentrations, as shown in Fig. 2g-i. Relatively, $\mathrm{PM}_{10}$ concentration seems more homogeneous in the YRD region, which implies that regional aerosol pollution is mainly induced by secondary reaction of multi-pollutants in the whole region. 


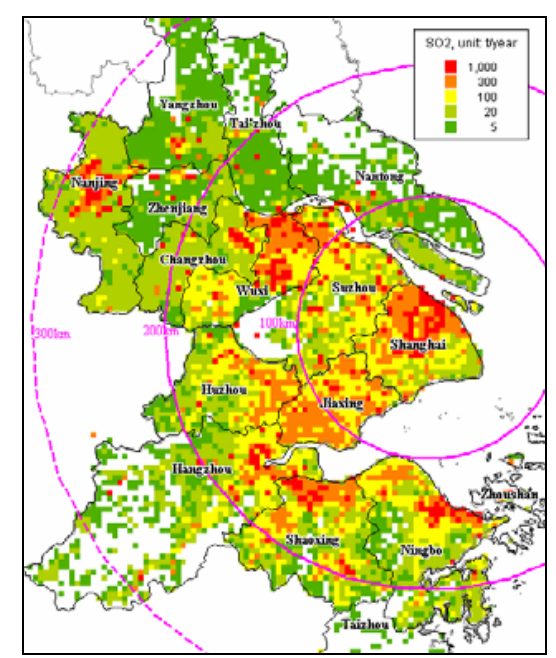

(a) $\mathrm{SO}_{2}$ emission

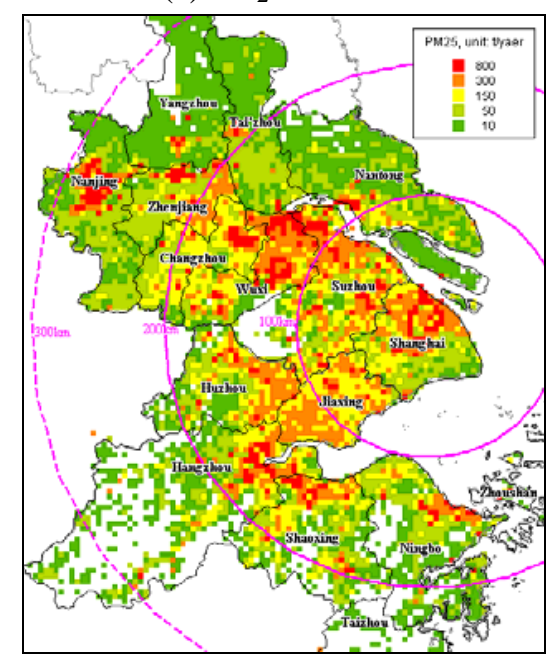

(d) $\mathrm{PM}_{2.5}$ emission

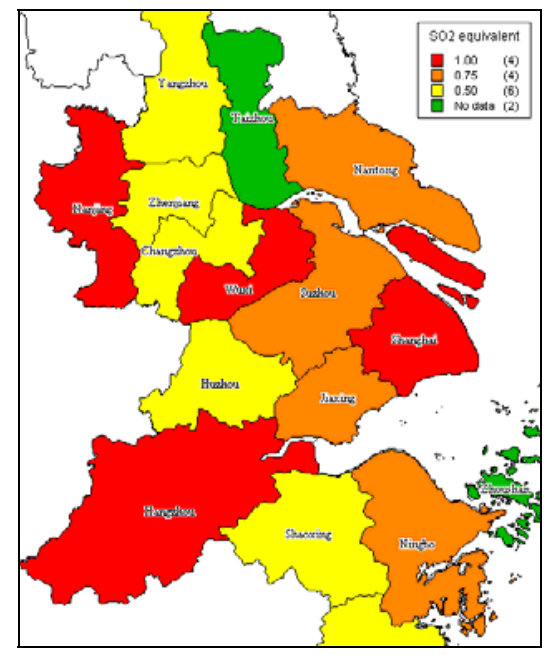

(g) $\mathrm{SO}_{2}$ concentration

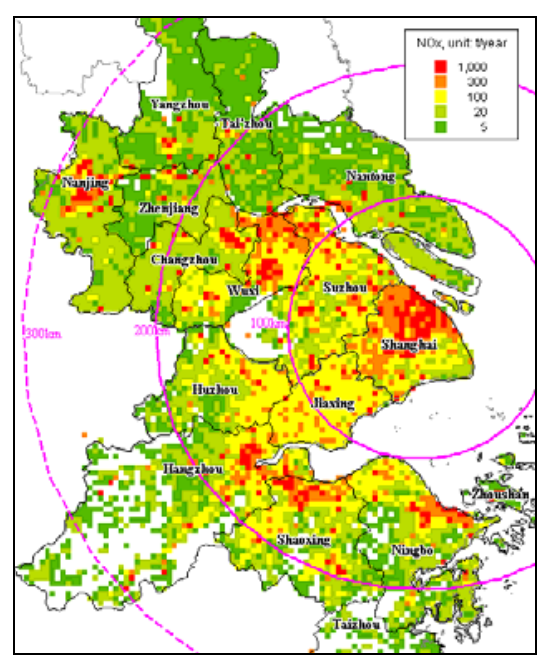

(b) $\mathrm{NO}_{x}$ emission

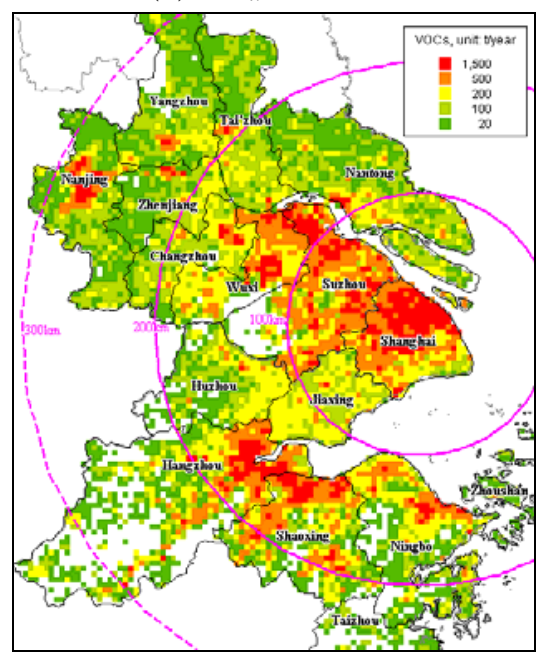

(e) VOCs emission

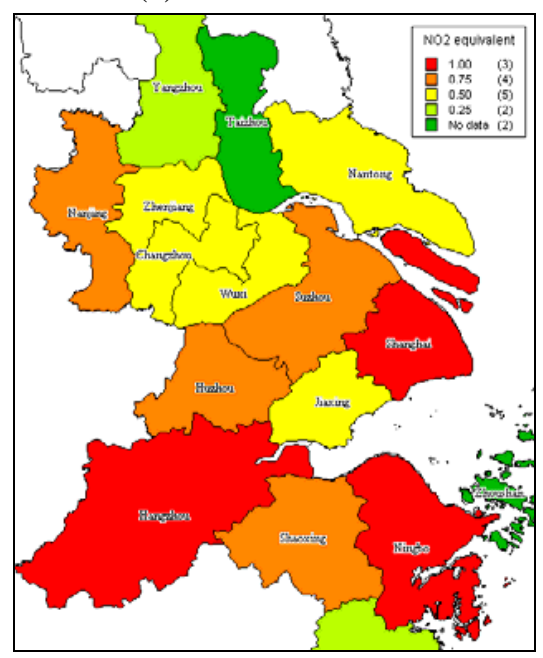

(h) $\mathrm{NO}_{2}$ concentration

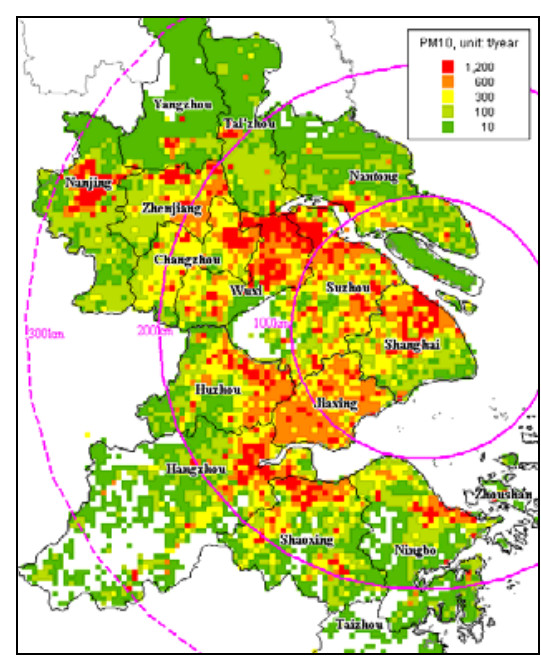

(c) $\mathrm{PM}_{10}$ emission

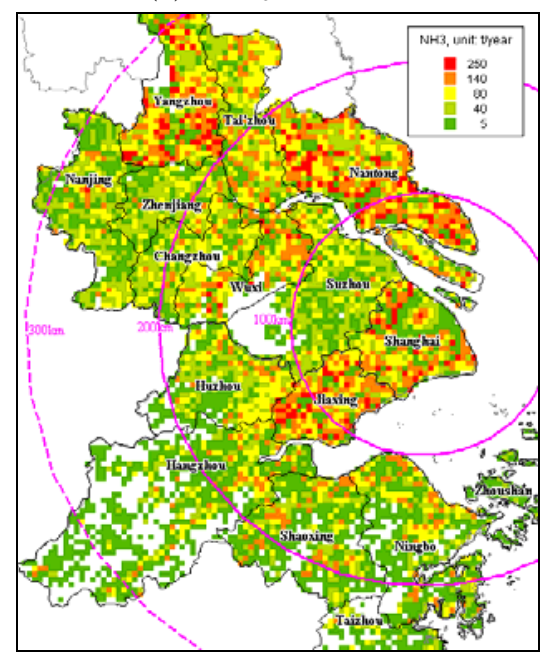

(f) $\mathrm{NH}_{3}$ emission

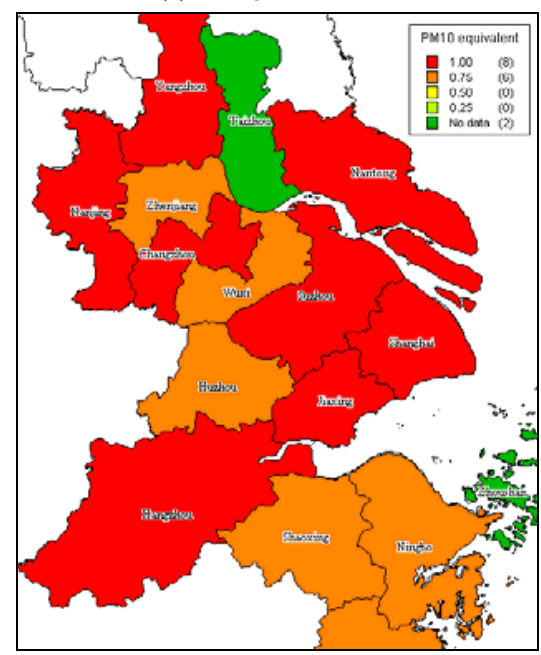

(i) $\mathrm{PM}_{10}$ concentration

Fig. 2. Spatial allocation of air pollutant emissions and annual concentrations in the YRD region in 2007. 


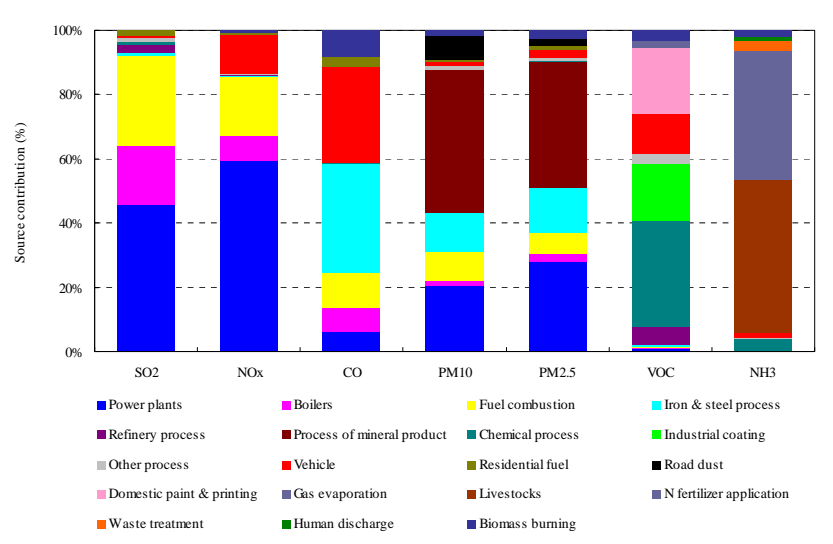

Fig. 3. Emission contribution of source categories in the YRD region in 2007.

\subsection{Emission contributions by source categories}

Figure 3 shows the emission contributions of more than 20 source categories in the YRD region. It is shown that power plants are the major pollution source of the primary pollutants, comprising $46 \%, 59 \%, 21 \%$, and $28 \%$ of the total $\mathrm{SO}_{2}, \mathrm{NO}_{\mathrm{x}}, \mathrm{PM}_{10}$, and $\mathrm{PM}_{2.5}$ emissions, respectively. The $\mathrm{SO}_{2}$ emission contribution of power plants will be reduced to about $19 \%$ when the FGD projects are accomplished in 2010. CO emission mainly comes from iron and steel manufacturing and on-road vehicles, which contribute $34 \%$ and $30 \%$ of the total, respectively. The non-combustion industrial processes, include iron and steel manufacturing, refineries, and paint and solvent use, are the major sources of fugitive dust and VOC, comprising $58 \%, 54 \%$, and $68 \%$ of $\mathrm{PM}_{10}, \mathrm{PM}_{2.5}$, and VOC emissions. The process of mineral production contributes $45 \%$ and $39 \%$ of $\mathrm{PM}_{10}$ and $\mathrm{PM}_{2.5}$ emission, respectively. Mineral production is a major industrial sector that includes the production of cement, lime, plate glass, and bricks, etc. Based on the study of Lei et al. (2008), the $\mathrm{PM}_{10}$ and $\mathrm{PM}_{2.5}$ emissions from cement production takes up $32 \%$ and $28 \%$ compared with the total $\mathrm{PM}_{10}$ and $\mathrm{PM}_{2.5}$ emissions in the 2006 INTEX-B data of China (Q. Zhang et al., 2009). Other VOC emission mainly comes from the domestic use of paint and solvent, gasoline evaporation, and biomass burning, contributing about $20 \%, 2 \%$, and $3 \%$ of the total. On-road vehicles contribute $12.3 \%$ and $12.4 \%$ of total $\mathrm{NO}_{\mathrm{x}}$ and VOC emissions. The $\mathrm{NH}_{3}$ emissions from livestock feeding and $\mathrm{N}$-fertilizer application take up $48 \%$ and $40 \%$ of the total, respectively. Based on the studies of Ge et al. (2011a, b), livestock feeding and N-fertilizer application might also be large sources of amines, whose tendency to partition into the particle phase is similar to or even greater than ammonia. However, determining the emission level of amines requires more future work in the YRD region. According to this inventory, the contributions of $\mathrm{SO}_{2}, \mathrm{NO}_{\mathrm{x}}$, $\mathrm{PM}_{10}, \mathrm{PM}_{2.5}, \mathrm{VOC}$, and $\mathrm{NH}_{3}$ emission for biomass burning

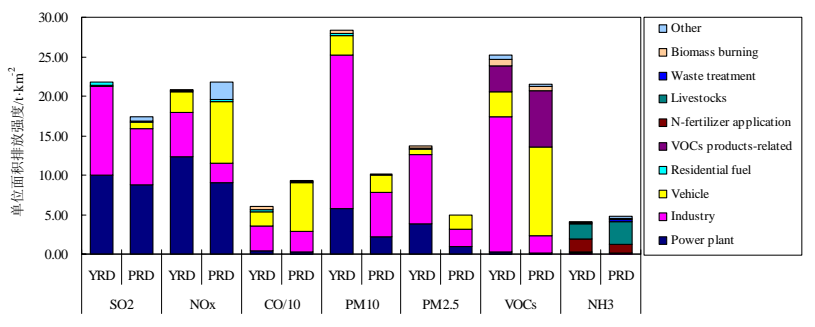

Fig. 4. Comparison of air pollutant emissions and source contributions in the YRD and PRD regions.

are $0.1 \%, 0.7 \%, 1.6 \%, 2.6 \%, 3.5 \%$, and $2.2 \%$. But it is necessary to emphasize that the crop residue burning emissions are usually concentrated in the spring harvest period during May to June and the autumn harvest period during September to October, which frequently correspond to the heavy pollution episodes in the YRD region.

\subsection{Comparison with emission inventories for other regions}

To better understand the emission level in the YRD region, we select another developed city cluster in southern China, the Pearl River Delta (PRD) region (including Guangzhou, Hong Kong, etc.), to compare their emission intensities of $\mathrm{SO}_{2}, \mathrm{NO}_{\mathrm{x}}, \mathrm{PM}_{10}, \mathrm{PM}_{2.5}$, VOCs, $\mathrm{NH}_{3}$, and source contributions as shown in Fig. 4. The emission data come from 2006 PRD emission inventories (Zheng et al., 2009b; Yin et al., 2010). The emission intensities of $\mathrm{SO}_{2}, \mathrm{NO}_{\mathrm{x}}$ and VOCs in the YRD and PRD regions are similar and all relatively high, reaching (22-25) $\mathrm{t} \mathrm{km}^{-2}$ and $(18-22) \mathrm{t} \mathrm{km}^{-2}$, respectively. However, the $\mathrm{PM}_{10}$ and $\mathrm{PM}_{2.5}$ emission intensities in the YRD region are more than 2.5 times the values in the PRD region. Primary particulate matter from power plants and industrial facilities could be the major contributors that need to be focused on for the air pollution control strategies in the YRD region. Relatively speaking, the industrial sector plays a more important role in the emissions of the YRD region. The statistical data indicate that the products of oil refining, ethylene, cement, iron, and steel in the YRD region are about 2.0, 1.8, 2.6, 7.8, and 6.3 times those of the same products in the PRD region (National Bureau of Statistics of China, 2008b). In contrast, road transport in the PRD region contributes more (about $36 \%$ and $53 \%$ of $\mathrm{NO}_{\mathrm{x}}$ and VOCs emissions) than that of the YRD region (about $12.3 \%$ and $12.4 \%$ of $\mathrm{NO}_{\mathrm{x}}$ and VOCs emissions).

To reveal the emission contributions of the YRD region to the whole of China, we compare our work to the national emission inventories for China (in Table 7), as published by the ACCMIP datasets (Lamarque et al., 2010), EDGAR v4.1 (EC-JRC/PBL, 2011), GAINS-Asia (Amann et al., 2008), and INTEX-B (Q. Zhang et al., 2009). Power generation is an important source of $\mathrm{SO}_{2}$ and $\mathrm{NO}_{\mathrm{x}}$ emissions. The power 
Table 7. Emission contributions of the YRD region to the whole China.

\begin{tabular}{lrrrrrl}
\hline & $\mathrm{SO}_{2}$ & $\mathrm{NO}_{\mathrm{x}}$ & $\mathrm{VOC}$ & $\mathrm{PM}_{10}$ & $\mathrm{PM}_{2.5}$ & References \\
\hline Power & & & & & & \\
YRD (2007)/China (2000) & $10 \%$ & $40 \%$ & - & - & - & Lamarque et al. (2010) \\
YRD (2007)/China (2005) & $5 \%$ & $11 \%$ & - & - & - & EC-JRC/PBL (2011) \\
YRD (2007)/China (2005) & $7 \%$ & $30 \%$ & - & $25 \%$ & $46 \%$ & Amann et al. (2008) \\
YRD (2007)/China (2006) & $6 \%$ & $15 \%$ & - & $26 \%$ & $28 \%$ & Q. Zhang et al. (2009) \\
Industry & & & & & & \\
YRD (2007)/China (2000) & $28 \%$ & $14 \%$ & $120 \%$ & - & - & Lamarque et al. (2010) \\
YRD (2007)/China (2005) & $10 \%$ & $10 \%$ & $34 \%$ & - & - & EC-JRC/PBL (2011) \\
YRD (2007)/China (2005) & $9 \%$ & $8 \%$ & $59 \%$ & $26 \%$ & $17 \%$ & Amann et al. (2008) \\
YRD (2007)/China (2006) & $13 \%$ & $12 \%$ & $23 \%$ & $20 \%$ & $14 \%$ & Q. Zhang et al. (2009) \\
Road transport & & & & & & \\
YRD (2007)/China (2005) & $23 \%$ & $16 \%$ & $14 \%$ & - & - & EC-JRC/PBL (2011) \\
YRD (2007)/China (2005) & $4 \%$ & $7 \%$ & $11 \%$ & $8 \%$ & $8 \%$ & Amann et al. (2008) \\
YRD (2007)/China (2006) & $14 \%$ & $6 \%$ & $5 \%$ & $10 \%$ & $10 \%$ & Q. Zhang et al. (2009) \\
Total & & & & & & \\
YRD (2007)/China (2000) & $13 \%$ & $20 \%$ & $12 \%$ & - & - & Lamarque et al. (2010) \\
YRD (2007)/China (2005) & $7 \%$ & $10 \%$ & $16 \%$ & - & - & EC-JRC/PBL (2011) \\
YRD (2007)/China (2005) & $8 \%$ & $14 \%$ & $17 \%$ & $17 \%$ & $12 \%$ & Amann et al. (2008) \\
YRD (2007)/China (2006) & $8 \%$ & $11 \%$ & $12 \%$ & $17 \%$ & $11 \%$ & Q. Zhang et al. (2009) \\
\hline
\end{tabular}

sector of the YRD generates nearly $20 \%$ of the electricity in China, and its $\mathrm{NO}_{\mathrm{x}}$ and $\mathrm{PM}_{10}$ emissions contribute about $11 \%-40 \%$ of the total compared with the studies mentioned above. The proportion of $\mathrm{SO}_{2}$ emissions in the YRD region is only $5 \%-10 \%$ due to the installation of FGD units in some power plants by 2007 . The industry sector of the YRD consumes $18 \%$ of the energy used in the industry sector of China, and its $\mathrm{SO}_{2}, \mathrm{NO}_{\mathrm{x}}, \mathrm{PM}_{10}$, and $\mathrm{PM}_{2.5}$ emissions contribute about $8 \%-28 \%$ of the total. The proportion of VOCs emission in industry of the YRD is relatively higher, about $23 \%-120 \%$ of the industry sector in China, which is mainly because there are a number of industrial activities with high VOCs emissions, such as oil refineries, petrochemical plants, etc., that have co-located in the YRD region. The road transport sector in the YRD region contributes $4 \%-23 \%$ of the emissions and $18 \%$ of automobile ownership. In general, the comparisons reveal that the YRD emission inventory in this study is in line with most of the national inventories. However, there are still some contradictions between this inventory and some studies which will require further investigation in the future.

The 2006 INTEX-B Asian emission inventory (Q. Zhang et al., 2009) is compared to this emission inventory. The result shows that the differences of $\mathrm{SO}_{2}, \mathrm{NO}_{\mathrm{x}}, \mathrm{PM}_{10}$ and VOCs emissions between the relative grids of both studies are about $-3.8 \%, 7.0 \%, 58.1 \%$ and $23.8 \%$, respectively. $\mathrm{SO}_{2}$ and $\mathrm{NO}_{\mathrm{x}}$ emissions have relatively high agreement, while the uncertainties of $\mathrm{PM}_{10}$ and VOCs emission in both inventories are all higher than the others. The correlation coefficients of the grids are about $0.81,0.80,0.78$ and 0.79 , implying similar spatial distribution patterns of emissions for the two studies. The emission intensities of $\mathrm{PM}_{10}$ and VOCs emission in this study are generally higher than INTEX-B. This might be because the activity data collected for this study are based on a bottom-up approach and are usually more detailed and concentrated in some grids compared with the nationalor continental-scale inventory.

\subsection{VOCs species emissions and ozone formation potentials}

Figure 5 shows the ten most important species for ozone formation potential and their relative emissions in the YRD region in 2007. The figure illustrates that ethylene, mp-xylene, o-xylene, toluene, 1,2,4-trimethylbenzene, 2,4dimethylpentane, ethyl benzene, propylene, 1-pentene, and isoprene are the key species for the formation of secondary air pollution. These 10 species contribute $77 \%$ to the total OFP and $49 \%$ to total VOC emissions in the region.

Figure 6 shows the source contributions of the ten most important species and total OFP in the YRD region. The emissions of ethylene, toluene, and 1-pentene mainly come from the chemical industry, contributing about $93 \%, 42 \%$, and $42 \%$, respectively. Painting and printing are the major sources of mp-xylene, o-xylene, and ethyl benzene, accounting for $42.5 \%, 61.1 \%$, and $41.9 \%$, respectively. Biomass burning takes up $45.8 \%$ and $54.3 \%$ of propylene and isoprene emissions. Gasoline vehicles contribute $20.0 \%, 36.3 \%, 11.5 \%$, and $11.2 \%$ of mp-xylene, $1,2,4-$ trimethylbenzene, propylene, and isoprene emission. 


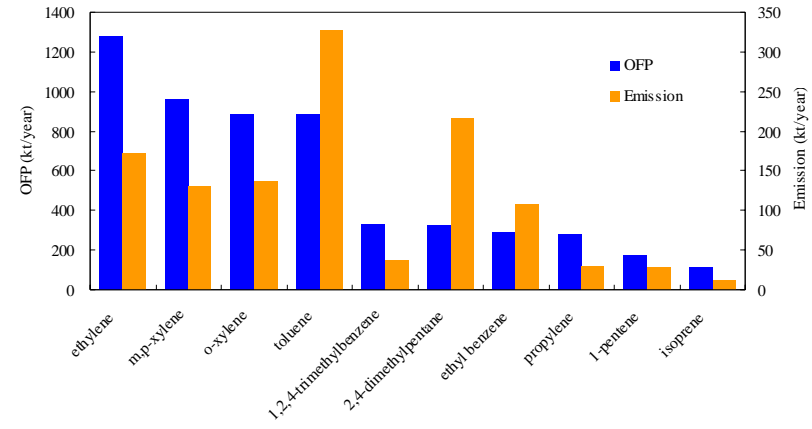

Fig. 5. The most important 10 VOC species of OFP contribution and their emissions in the YRD in 2007.

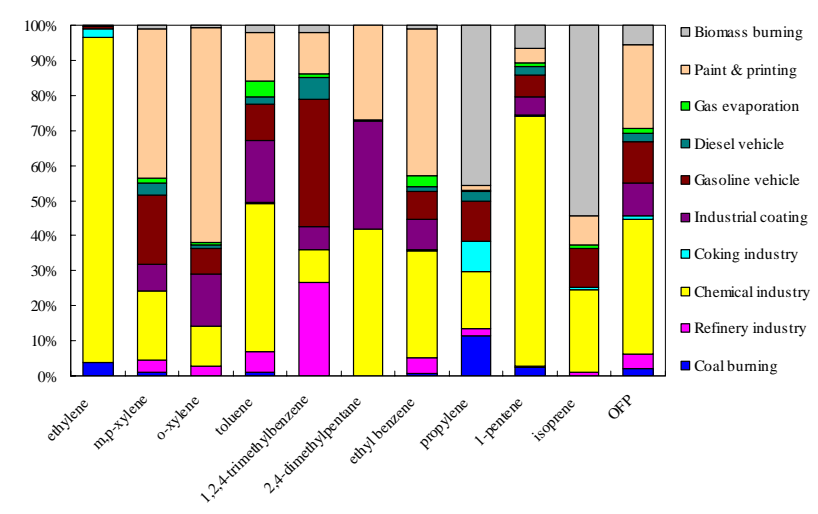

Fig. 6. Source contributions of the most important 10 VOC species and OFP in the YRD region.

In terms of OFP, chemical industry, domestic paint and printing, gasoline vehicles, industrial coating, and oil refineries are the five major sources for ozone formation, accounting for $38.2 \%, 23.9 \%, 11.6 \%, 9.6 \%$, and $4.2 \%$, respectively. The VOC emission contributions of these sources are about $34.5 \%, 21.7 \%, 9.7 \%, 18.8 \%$, and $6.0 \%$, respectively. The results shows the ozone formation contributions of the sources are not always correlated with their emission values in the YRD region. It is worthwhile to mention that gasoline vehicles are responsible for $9.7 \%$ of VOC emissions, as well as $11.6 \%$ for ozone formation. Figure 7 shows the spatial allocation of the OFPs in the YRD region. It can be seen from the figure that high OFP values are mainly concentrated in the well-developed urban and industrial areas along the Yangtze River and around Hangzhou Bay.

\subsection{Assessment of uncertainty in the emission inventory}

The YRD regional emission inventory was compiled by a bottom-up approach based on local surveys of major air pollution sources in the region. Most of the activity data, including fuel consumption, sulfur content, ash content, exhaust control efficiency and geographic location of industrial

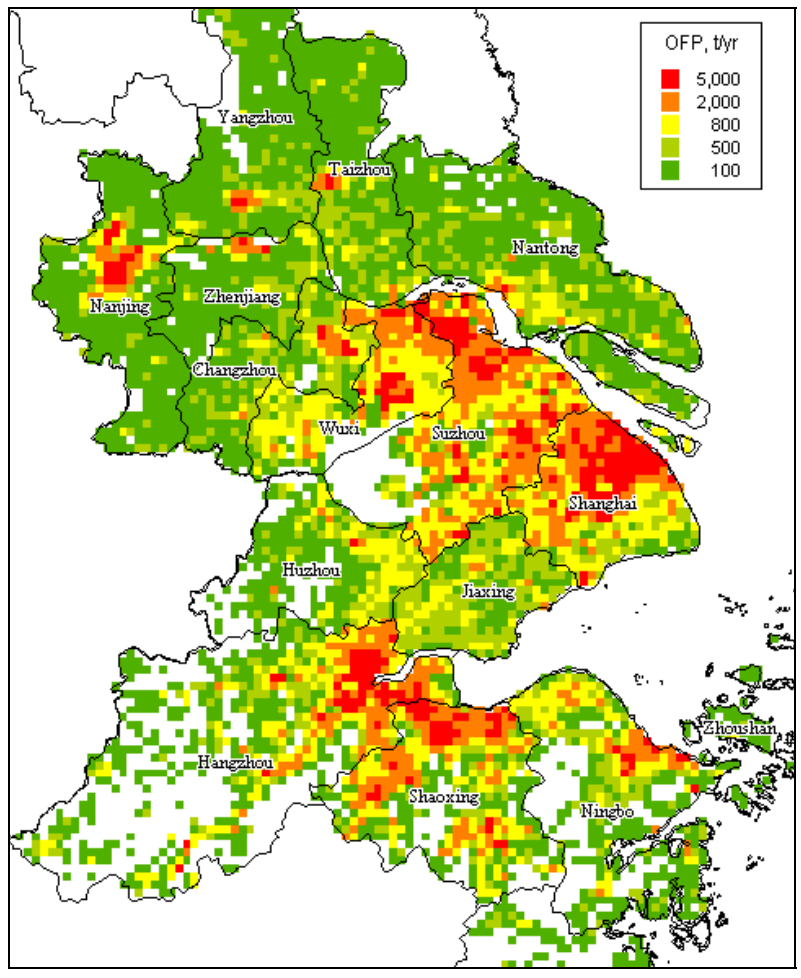

Fig. 7. Spatial distribution of the OFPs in the YRD region.

sources, were collected from the local pollution source census in the YRD region. However, most of the emission factors used in this study is still subject to considerable uncertainty due to the lack of local measurement data. Table 8 illustrates the uncertainty analysis at the $95 \%$ confidence interval for each source category in the emission inventory. The coefficients of variation of the activity and emission factor data of each source are classified into seven grades in the range of $2 \%-100 \%$ based on expert judgment. The coefficient of activity data is determined based on the quality of data source. The census data of the industrial sources are assigned the lowest coefficient of uncertainties, while the estimated activity data based on statistical yearbooks such as biomass burning are assigned the highest values. The coefficient of emission factor is mainly determined by its source. The emission factors based on local measurements with large samples are assigned the lowest values, while those from limited European or American studies are assigned high coefficients. Then the uncertainty of each pollutant from each emission source is combined by Eqs. (1-3).

$$
\begin{aligned}
& C V=\frac{U}{E}=1.96 \times \sqrt{\left(1+C_{a}^{2}\right)\left(1+C_{f}^{2}\right)-1} \\
& U_{j}=\sqrt{\sum_{k} U_{j, k}^{2}}
\end{aligned}
$$


Table 8. Uncertainty assessment of major emission sources in the YRD region.

\begin{tabular}{lrrrrrrr}
\hline Sources & $\mathrm{SO}_{2}$ & $\mathrm{NO}_{\mathrm{x}}$ & $\mathrm{CO}$ & $\mathrm{PM}_{10}$ & $\mathrm{PM}_{2.5}$ & $\mathrm{VOCs}$ & $\mathrm{NH}_{3}$ \\
\hline Power plants & $\pm 5.5 \%$ & $\pm 5.5 \%$ & $\pm 66.8 \%$ & $\pm 35.5 \%$ & $\pm 98.1 \%$ & $\pm 98.1 \%$ & - \\
Boilers & $\pm 5.5 \%$ & $\pm 35.5 \%$ & $\pm 66.8 \%$ & $\pm 35.5 \%$ & $\pm 98.1 \%$ & $\pm 98.1 \%$ & - \\
Other fuel combustion & $\pm 50.3 \%$ & $\pm 76.4 \%$ & $\pm 76.4 \%$ & $\pm 76.4 \%$ & $\pm 136.1 \%$ & $\pm 105.6 \%$ & - \\
Iron \& steel process & - & - & $\pm 123.1 \%$ & $\pm 123.1 \%$ & $\pm 213.5 \%$ & - & - \\
Refinery process & - & - & - & - & - & $\pm 96.9 \%$ & - \\
Process of mineral product & - & - & - & $\pm 152.0 \%$ & $\pm 213.5 \%$ & - & - \\
Chemical process & - & - & - & - & - & $\pm 152.0 \%$ & - \\
Industrial coating & - & - & - & - & - & $\pm 152.0 \%$ & - \\
Vehicle & $\pm 50.3 \%$ & $\pm 50.3 \%$ & $\pm 50.3 \%$ & $\pm 76.4 \%$ & $\pm 76.4 \%$ & $\pm 50.3 \%$ & $\pm 136.1 \%$ \\
Road dust & - & - & - & $\pm 201.9 \%$ & $\pm 264.0 \%$ & - & - \\
Domestic paint \& printing & - & - & - & - & - & $\pm 147.0 \%$ & - \\
Gas evaporation & - & - & - & - & - & $\pm 76.4 \%$ & - \\
Livestocks & - & - & - & - & - & - & $\pm 105.6 \%$ \\
$\mathrm{~N}$ fertilizer application & - & - & - & - & - & $\pm 136.1 \%$ \\
Biomass burning & $\pm 152.0 \%$ & $\pm 152.0 \%$ & $\pm 152.0 \%$ & $\pm 182.4 \%$ & $\pm 213.5 \%$ & $\pm 152.0 \%$ & - \\
\hline
\end{tabular}

$U=\sqrt{\sum_{j} U_{j}^{2}}$

where, $C V$ is the coefficient of variation of the emission rate, $E$ is the emission rate, $U$ is the uncertainty of the emission source, $C_{\mathrm{a}}$ is the uncertainty of activity data, $C_{\mathrm{f}}$ is the uncertainty of emission factor, $j$ and $k$ represent for pollutant and emission source respectively.

The uncertainty assessment indicates that the fuel-related combustion sources such power plants and boilers are more reliable compared with the other source categories, because the emissions are calculated based on detailed census data of fuel consumption, technology, and exhaust control efficiency. The industrial processes, including iron and steel production, oil refinery, mineral products process, and chemical production, etc., have relatively higher uncertainties mainly due to the lack of local emission factors for each production process and exhaust control technology. Vehicle emissions are expected to have low uncertainties. Vehicle emission factors have been modified by real-world measurement data in Shanghai (Chen et al., 2007; H. K. Wang et al., 2008), and average mileage data is adjusted by the statistical data of gasoline and diesel consumption in each region. Relatively, road dust emissions have much high uncertainty since the parameters have large differences in different areas. Other emission sources like domestic painting and printing, fertilizer application, and biomass burning all have high uncertainties in the study. More research is necessary both on emission factors and on activity surveys in the future in the YRD region.

The overall uncertainties for $\mathrm{SO}_{2}, \mathrm{NO}_{\mathrm{x}}, \mathrm{CO}, \mathrm{PM}_{10}, \mathrm{PM}_{2.5}$, VOCs, and $\mathrm{NH}_{3}$ emissions in the inventory are, respectively, $\pm 19.1 \%, \pm 27.7 \%, \pm 47.1 \%, \pm 117.4 \%, \pm 167.6 \%$, $\pm 133.4 \%$, and $\pm 112.8 \%$. The uncertainties of $\mathrm{SO}_{2}, \mathrm{NO}_{\mathrm{x}}$, and $\mathrm{CO}$ are improved due to the fact that the activity data of major emission sources such as power plants, boilers, and other fuel combustion facilities are refined by the bottom-up approach. However, $\mathrm{PM}_{10}, \mathrm{PM}_{2.5}$, VOCs, and $\mathrm{NH}_{3}$ emissions still have high uncertainty, since their emission factors are mainly taken from the research findings in the United States and Europe, which result in large differences compared with the real situation in the YRD region.

There are still some sources not considered in this study, such as off-road emission sources, including locomotives, shipping, aircraft, and construction machinery, and dust emissions from yards and construction sites. The omission of these sources will cause a slight underestimate in the emission inventory. In addition, many studies have confirmed the impact of biogenic sources on the air quality. Our study did not include biogenic emissions in the YRD region, but it can be roughly estimated that biogenic VOC emissions comprise $23 \%$ of the total in the summer and $3 \%$ of the total VOC emissions in the winter, using the GEIA natural VOC emission database for 1990 .

\section{Conclusions and recommendations}

A regional emission inventory for the YRD region for the year 2007 was compiled based on local source information, urban energy consumption, vehicle composition, as well as other information on the industry, commercial and agriculture sectors. It is estimated that the emissions of $\mathrm{SO}_{2}, \mathrm{NO}_{\mathrm{x}}$, $\mathrm{CO}, \mathrm{PM}_{10}, \mathrm{PM}_{2.5}, \mathrm{VOCs}$ and $\mathrm{NH}_{3}$ in the YRD region account for $2392 \mathrm{kt}, 2293 \mathrm{kt}, 6697 \mathrm{kt}, 3116 \mathrm{kt}, 1511 \mathrm{kt}, 2767 \mathrm{kt}$, and $459 \mathrm{kt}$, respectively. The percentages of alkanes, alkenes, and aromatics in the total VOC emission are $44 \%, 11 \%$, and $36 \%$, respectively. Ethylene, mp-xylene, o-xylene, toluene, 
1,2,4-trimethylbenzene, 2,4-dimethylpentane, ethyl benzene, propylene, 1-pentene, and isoprene are the key species which contribute $77 \%$ to the total OFP and $49 \%$ to the VOC emission in the whole region. The air pollutant emissions and OFPs in the YRD region were mainly concentrated in the urban and industrial areas along the Yangtze River and around Hangzhou Bay, where the conventional air pollutant concentrations are relatively high.

The industrial sources including power plants, other fuel combustion facilities, and non-combustion processes are the major contributors to in the YRD region, generally account for $97 \%, 86 \%, 89 \%, 91 \%$, and $69 \%$ of the total $\mathrm{SO}_{2}$, $\mathrm{NO}_{\mathrm{x}}, \mathrm{PM}_{10}, \mathrm{PM}_{2.5}$, and VOC emissions. On-road vehicles in the YRD region contribute $12.3 \%$ of the $\mathrm{NO}_{\mathrm{x}}$ emission and $12.4 \%$ of the VOC emission. The livestock feeding and $\mathrm{N}$-fertilizer application source take up $48 \%$ and $40 \%$ of the total $\mathrm{NH}_{3}$ emission, respectively. In addition, chemical industry, domestic paint \& printing, gasoline vehicle, industrial coating, and oil refinery are the five major sources to the ozone formation, accounting for $38 \%, 24 \%, 12 \%, 10 \%$, and $4 \%$, respectively.

$\mathrm{NO}_{\mathrm{x}}$ and VOC emissions are the key precursors required to be reduced to improve the regional ozone and secondary aerosol pollution. However, neither of the pollutants is regulated currently in China. Therefore, more targeted air pollution control measures on reducing $\mathrm{NO}_{\mathrm{x}}$ and VOC emissions are needed to be put forward in the national or regional planning. Based on the emission inventory in the YRD region, power plants and vehicles should be taken into accounts to reduce the $\mathrm{NO}_{\mathrm{x}}$ emission. In this case, some control measures such as denitrification of power plants, universally upgrading new vehicle emission standard and fuel quality (Shanghai has implemented Euro IV standard in 2009), should be considered in the next stage for the cities of the YRD region. VOC emissions are more complicated to be controlled. The control measures of supervising the fugitive VOC emission in the refining, chemical, and other industries, gasoline vapor recovery, and the use of water-based paint are expected to reduce the total VOC emissions in the YRD region. In addition, considering most of the gasoline vehicle emissions are concentrated in urban areas and have strong reactivity to ozone formation, some corresponding measures such as accelerating the phase out of old vehicles and strengthening vehicle inspection and maintenance would be more effective to the mitigation of ozone concentration.

Acknowledgements. This study was supported by the "Chinese National Key Technology R\&D Program” via grants 2009BAK43B33 and "The characteristics of haze and control strategy in the typical areas in China" via grants HY10096784. We would like to show our gratitude to Chinese Research Academy of Environmental Sciences very much for their data support on the study.

Edited by: T. Butler

\section{References}

Akimoto, $\mathrm{H}$. and Narita, $\mathrm{H}$.: Distribution of $\mathrm{SO}_{2}, \mathrm{NOx}$, and $\mathrm{CO}_{2}$ emissions from fuel combustion and industrial activities in Asia with $1^{\circ} \times 1^{\circ}$ resolution, Atmos. Environ., 28, 213-225, 1994.

Amann, M., Jiang, K. J., Hao, J. M., Wang, S. X., Zhuang, X., Wei, W., Deng, Y. X., Liu, H., Xing, J., Zhang, C. Y., Bertok, I., Borken. J., Cofala, J., Heyes, C., Höglund, L., Klimont, Z., Purohit, P., Rafaj, P., Schöpp, W., Toth, G., Wagner, F., and Winiwarter, W.: Scenarios for cost-effective control of air pollution and greenhouse gases in China. International Institute for Applied Systems Analysis (IIASA), Laxenburg, Austria, 2008.

Andreae, M. O. and Merlet, P.: Emission of trace gases and aerosols from biomass burning, Global Biogeochem. Сy., 15, 955-966, 2001.

Bo, Y., Cai, H., and Xie, S. D.: Spatial and temporal variation of historical anthropogenic NMVOCs emission inventories in China, Atmos. Chem. Phys., 8, 7297-7316, doi:10.5194/acp-8-72972008, 2008.

Cao, G. L., Zhang, X. Y., Wang, D., and Zheng, F. C.: Inventory of atmospheric pollutants discharged from biomass burning in China continent, China Environmental Science, 25(1), 389-393, 2005 (in Chinese).

Cao, G. L., Zhang, X. Y., and Zheng, F. C.: Inventory of black carbon and organic carbon emissions from China, Atmos. Environ., 40, 6516-6527, 2006.

Carter, W. P. L.: Development of ozone reactivity scales for volatile organic compounds, J. Air Waste Manage. Assoc., 44, 881-899, 1994.

Chen, C. H., Wang, B. Y., Fu, Q. Y., Green, C., and Streets, D. G.: Reductions in emissions of local air pollutants and co-benefits of Chinese energy policy: a Shanghai case study, Energy Policy, 34(3), 754-762, 2006.

Chen, C. H., Huang, C., Jing, Q. G., Wang, H. K., Pan, H. S., Li, L., Zhao, J., Dai, Y., Huang, H. Y., Schipper, L., and Streets, D. G.: On-road emission characteristics of heavy-duty diesel vehicles in Shanghai, Atmos. Environ., 41(26), 5334-5344, 2007.

Dong, Y. Q., Chen, C. H., Huang, C., Wang, H. L., Li, L., Dai, P., and Jia, J. H.: Anthropogenic emissions and distribution of ammonia over the Yangtze River Delta. Acta Scientiae Circumstantiae, 29(8), 1-7, 2009 (in Chinese).

European Commission: Joint Research Centre (JRC)/Netherlands Environmental Assessment Agency (PBL), Emission Database for Global Atmospheric Research (EDGAR), release version 4.1, http://edgar.jrc.ec.europa.eu/index.php, (last access: 2 April 2010), 2011.

European Environment Agency (EEA): EMEP/CORINAIR emission inventory guidebook-2006. No. 1112006 Denmark: European Environment, 2006

Gao, J., Wang, T., Zhou, X. H., Wu, W. X., and Wang, W. X.: Measurement of aerosol number size distributions in the Yangtze River delta in China: Formation and growth of particles under polluted conditions, Atmos. Environ., 43, 829-836, 2009.

Ge, S., Bai, Z. P., Liu, W. L., Zhu, T., Wand T. J., Qing, S., and Zhana, J.: Boiler briquette coal versus raw coal : Part I - Stack gas emissions, J. Air Waste Manage. Assoc., 51, 524-533, 2001.

Ge, X. L., Wexler, A. S., and Clegg, S. L.: Atmospheric amines-Part I. A review, Atmos. Environ., 45, 524-546, $2011 \mathrm{a}$.

Ge, X. L., Wexler, A. S., and Clegg, S. L.: Atmospheric aminesPart II. Thermodynamic properties and gas/particle partitioning, 
Atmos. Environ., 45, 561-577, $2011 \mathrm{~b}$.

Geng, F. H., Zhang, Q., Tie, X. X., Huang, M. Y., Ma, X. C., Deng, Z. Z., Yu, Q., Quan, J. N., and Zhao, C. S.: Aircraft measurements of $\mathrm{O}_{3}, \mathrm{NO}_{\mathrm{x}}, \mathrm{CO}$, VOCs, and $\mathrm{SO}_{2}$ in the Yangtze River Delta region, Atmos. Environ., 43, 584-593, 2009.

Guo, H., Zhang, Q. Y., Shi, Y., and Wang, D. H.: On-road remote sensing measurements and fuel-based motor vehicle emission inventory in Hangzhou, China, Atmos. Environ., 41, 3095-3107, 2007.

Hao, J., Tian, H., and Lu, Y.: Emission inventories of NOx from commercial energy consumption in China, 1995-1998, Environ. Sci. Technol., 36, 552-560, 2002.

Hao, C. and Xie, S. D.: Estimation of vehicular emission inventories in China from 1980 to 2005, Atmos. Environ., 41, 8963-8979, 2007

Huang, Y. M., Shu, J., Wei, H. P., and Wang, Q.: The estimate and GIS of fugitive dust emission from paved roads in industrial estate, Environ. Sci. Manage., 31(1), 46-52, 2006 (in Chinese).

ISSRC: IVE model users manual version 1.1.1. Document available online at: http://www.gssr.net/ive/, 2004.

Jiangsu Environment Protection Bureau (JSEPB): Jiangsu Provincial Environment Bulletin 2008, Jiangsu Environment Protection Bureau press, Jiangsu, 2008 (in Chinese).

Kato, N. and Akimoto, H.: Anthropogenic emissions of $\mathrm{SO}_{2}$ and $\mathrm{NO}_{\mathrm{X}}$ in Asia: Emission inventories, Atmos. Environ., 26, $2997-$ 3017, 1992.

Klimont, Z., Cofala, J., Bertok, I., Amann, M., Heyes, C., and Gyarfas, F.: Modelling particulate emissions in Europe: A framework to estimate reduction potential and control costs. Interim report, IR-02-076, International Institute for Applied Systems Analysis, Laxenburg, Austria, 2002a.

Klimont, Z., Streets, D. G., Gupta, S., Cofala, J., Fu, L. X., and Ichikawa, Y.: Anthropogenic emissions of non-methane volatile organic compounds in China, Atmos. Environ., 36, 1309-1322, $2002 b$.

Lamarque, J.-F., Bond, T. C., Eyring, V., Granier, C., Heil, A., Klimont, Z., Lee, D., Liousse, C., Mieville, A., Owen, B., Schultz, M. G., Shindell, D., Smith, S. J., Stehfest, E., Van Aardenne, J., Cooper, O. R., Kainuma, M., Mahowald, N., McConnell, J. R., Naik, V., Riahi, K., and van Vuuren, D. P.: Historical (1850-2000) gridded anthropogenic and biomass burning emissions of reactive gases and aerosols: methodology and application, Atmos. Chem. Phys., 10, 7017-7039, doi:10.5194/acp10-7017-2010, 2010.

Lei, Y., He, K. B., Zhang, Q., and Liu, Z. Y.: Technology-based emission inventory of particulate matters (PM) from cement industry, Environ. Sci., 29(8), 2366-2371, 2008 (in Chinese).

Li, L., Chen, C. H., Fu, J. S., Huang, C., Streets, D. G., Huang, H. Y., Zhang, G. F., Wang, Y. J., Jang, C. J., Wang, H. L., Chen, Y. R., and Fu, J. M.: Air quality and emissions in the Yangtze River Delta, China, Atmos. Chem. Phys., 11, 16211639, doi:10.5194/acp-11-1621-2011, 2011.

Liu, Y., Shao, M., Fu, L. L., Lu, S. H., Zeng, L. M., and Tang, D. G.: Source profiles of volatile organic compounds (VOCs) measured in China: Part I, Atmos. Environ., 42, 6247-6260, 2008.

Liu, X. H., Zhang Y., Cheng, S. H., Xing, J., Zhang, Q., Streets, D. G., Jang, C., Wang, W. X., and Hao, J. M.: Understanding of regional air pollution over China using CMAQ, part I performance evaluation and seasonal variation, Atmos. Environ., 44,
2415-2426, 2010.

National Bureau of Statistics of China: China Energy Statistical Yearbook 2008. China Statistics Press, Beijing, 2008a.

National Bureau of Statistics of China: China Statistical Yearbook 2008. China Statistics Press, Beijing, 2008b.

Oak Ridge National Laboratory (ORNL): LandScan global population 2006 database. Oak Ridge National Laboratory, Oak Ridge, Tenn., 2007.

Ohara, T., Akimoto, H., Kurokawa, J., Horii, N., Yamaji, K., Yan, X., and Hayasaka, T.: An Asian emission inventory of anthropogenic emission sources for the period 1980-2020, Atmos. Chem. Phys., 7, 4419-4444, doi:10.5194/acp-7-4419-2007, 2007.

Passant, N. R. and Vincent, K.: Review of the efficiency and cost of control measures for sulphur dioxide and volatile organic compounds, Draft final report AEAT-3851, AEA Technology, Culham, UK, 1998.

Resource and Environmental Science Data Center: National $1 \mathrm{~km}$ $\times 1 \mathrm{~km}$ GDP data, 2003, available online at: http://www.resdc. $\mathrm{cn} / \mathrm{UA} /, 2003$.

Shanghai Environment Protection Bureau (SEPB): Shanghai Environment Bulletin 2008. Shanghai Environment Protection Bureau press, Shanghai, 2008 (in Chinese).

Streets, D. G., Gupta, S., Waldhoff, S. T., Wang, M. Q., Bond, T. C., and Bo, Y.: Black carbon emissions in China, Atmos. Environ., 35, 4281-4296, 2001

Streets, D. G., Bond, T. C., Carmichael, G. R., Fernandes, S. D., Fu, Q., He, D., Klimont, Z., Nelson, S. M., Tsai, N. Y., Wang, M. Q., Woo, J. H., and Yarber, K. F.: An inventory of gaseous and primary aerosol emissions in Asia in the year 2000, J. Geophys. Res., 108(D21), 8809, doi:10.1029/2002JD003093, 2003.

Sun, J., Shu, J., and Lu, X. Q.: Remote sensing interpretation and its management information system of fugitive dust pollution sources in Shanghai, Shanghai Environmental Sciences, 22(2), 295-301, 2003 (in Chinese).

Tian, H. Z.: Studies on present and future emissions of nitrogen oxides and its comprehensive control polices in China, Ph.D. thesis, Tsinghua University, China, Beijing, 2003 (in Chinese).

Tie, X. X. and Cao, J. J.: Aerosol pollution in China: Present and future impact on environment, Particuology, 7(3), 426-431, 2009.

U.S. Environmental Protection Agency (USEPA): Compilation of air pollutant emission Factors, AP-42, 5th ed., Washington, DC, 2002.

Wang, B. G., Zhang, Y. H., Shao, M., Zhou, Y., and Feng, Z. C.: Sources apportionment of anthropogenic C2 C9 non-methane hydrocarbons in the atmosphere of Guangzhou, China, Acta Scientiae Circumstantiae, 7, 1430-1440, 2008 (in Chinese).

Wang, H. K., Chen, C. H., Huang, C., and Fu, L. X.: On-road vehicle emission inventory and its uncertainty analysis for Shanghai, China, Sci. Total Environ., 398(1-3), 60-67, 2008.

Wang, L. T., Zhang, Q., Hao, J. M., and He, K. B.: Anthropogenic $\mathrm{CO}$ emission inventory of Mainland China, Acta Scientiae Circumstantiae, 25(12), 1580-1585, 2005 (in Chinese).

Wei, W., Wang, S. X., Chatani, S., Klimont, Z., Cofala, J., and Hao, J. M.: Emission and speciation of non-methane volatile organic compounds from anthropogenic sources in China, Atmos. Environ., 42, 4976-4988, 2008.

Yan, X., Ohara, T., and Akimoto, H.: Bottom-up estimate of biomass burning in mainland China, Atmos. Environ., 40, 5262- 
5273, 2006.

Yin, S. S., Zheng, J. Y., Zhang, L. J., and Zhong, L. J.: Anthropogenic ammonia emission inventory and characteristics in the Pearl River Delta region, Environ. Sci., 31(2), 1146-1151, 2010 (in Chinese).

Yuan, B., Shao, M., Lu, S. H., and Wang, B.: Source profiles of volatile organic compounds associated with solvent use in Beijing, China, Atmos. Environ., 44(15), 1919-1926, 2010.

Zhang, C. Y., Wang, S. X., Zhao, Y., and Hao, J. M.: Current status and future prospects of anthropogenic particulate matter emissions in China, Environ. Sci., 30(7), 1881-1887, 2009 (in Chinese).

Zhang, J., Smith, K. R., Ma, Y., Ye, S., Jiang, F., Qi, W., Liu, P., Khalil, M. A. K., Rasmussen, R. A., and Thorneloe, S. A.: Greenhouse gases and other airborne pollutants from household stoves in China: a data base for emission factors, Atmos. Environ., 34, 4537-4549, 2000.

Zhang, Q.: Study on Regional Fine PM Emissions and Modeling in China, Ph.D. thesis, Tsinghua University, China, Beijing, 2005 (in Chinese).

Zhang, Q., Streets, D. G., He, K. B., Wang, Y. X., Richter, A., Burrows, J. P., Uno, I. Jang, C., Chen, D., Yao, Z. L., and Lei, Y.: $\mathrm{NO}_{\mathrm{x}}$ emission trend for China, 1995-2004: the view from the ground and the view from space, J. Geophys. Res., 112, D22306, doi:10.1029/2007JD008684, 2007.
Zhang, Q., Streets, D. G., Carmichael, G. R., He, K. B., Huo, H., Kannari, A., Klimont, Z., Park, I. S., Reddy, S., Fu, J. S., Chen, D., Duan, L., Lei, Y., Wang, L. T., and Yao, Z. L.: Asian emissions in 2006 for the NASA INTEX-B mission, Atmos. Chem. Phys., 9, 5131-5153, doi:10.5194/acp-9-5131-2009, 2009.

Zhang, Q. Y., Wei, Y. M., Tian, W. L., and Yang, K. M.: GIS-based emission inventories of urban scale: A case study of Hangzhou, China, Atmos. Environ., 42, 5150-5165, 2008.

Zhang, Y., Dore, A. J., Ma, L., Liu, X. J., Ma, W. Q., Cape, J. N., and Zhang, F. S.: Agricultural ammonia emissions inventory and spatial distribution in the North China Plain, Environ. Pollut., 158, 490-501, 2010.

Zhejiang Environment Protection Bureau (ZJEPB): Zhejiang Provincial Environment Bulletin 2008.Zhejiang Environment Protection Bureau press, Jiangsu, 2008 (in Chinese).

Zheng, J. Y., Shao, M., Che, W. W., Zhang, L. J., Zhong, L. J., Zhang, Y. H., and Streets, D. G.: Speciated VOC emission inventory and spatial patterns of ozone formation potential in the Pearl River Delta, China, Environ. Sci. Technol., 43, 8580-8586, 2009a.

Zheng, J. Y., Zhang, L. J., Che, W. W., Zheng, Z. Y., and Yin, S. S.: A highly resolved temporal and spatial air pollutant emission inventory for the Pearl River Delta region, China and its uncertainty assessment, Atmos. Environ., 43, 5112-5122, 2009 b. 